
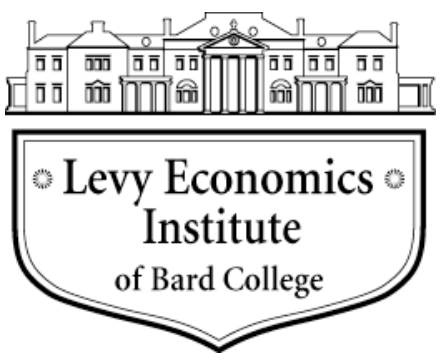

Working Paper No. 849

\title{
Bank Leverage Ratios and Financial Stability: A Micro- and Macroprudential Perspective
}

\author{
by
}

\author{
Emilios Avgouleas* \\ University of Edinburgh
}

October 2015

\begin{abstract}
* Professor (Chair) of International Banking Law and Finance, Head of Commercial Law, University of Edinburgh.

The part of the paper discussing leverage ratios and leverage governance costs draws on past work jointly undertaken with Dr. Jay Cullen of Sheffield University. The part of the paper dealing with macro stability and the interaction between bank leverage and monetary policy is brand-new research solely undertaken by the author. I have greatly benefited from feedback I have received from Charles Goodhart, Martin Hellwig, and Susan Wachter. The usual disclaimers apply.
\end{abstract}

The Levy Economics Institute Working Paper Collection presents research in progress by Levy Institute scholars and conference participants. The purpose of the series is to disseminate ideas to and elicit comments from academics and professionals.

Levy Economics Institute of Bard College, founded in 1986, is a nonprofit, nonpartisan, independently funded research organization devoted to public service. Through scholarship and economic research it generates viable, effective public policy responses to important economic problems that profoundly affect the quality of life in the United States and abroad.

Levy Economics Institute P.O. Box 5000

Annandale-on-Hudson, NY 12504-5000

http://www.levyinstitute.org

Copyright (C) Levy Economics Institute 2015 All rights reserved 


\begin{abstract}
Bank leverage ratios have made an impressive and largely unopposed return; they are mostly used alongside risk-weighted capital requirements. The reasons for this return are manifold, and they are not limited to the fact that bank equity levels in the wake of the global financial crisis (GFC) were exceptionally thin, necessitating a string of costly bailouts. A number of other factors have been equally important; these include, among others, the world's revulsion with debt following the GFC and the eurozone crisis, and the universal acceptance of Hyman Minsky's insights into the nature of the financial system and its role in the real economy. The best examples of the causal link between excessive debt, asset bubbles, and financial instability are the Spanish and Irish banking crises, which resulted from nothing more sophisticated than straightforward real estate loans. Bank leverage ratios are primarily seen as a microprudential measure that intends to increase bank resilience. Yet in today's environment of excessive liquidity due to very low interest rates and quantitative easing, bank leverage ratios should also be viewed as a key part of the macroprudential framework. In this context, this paper discusses the role of leverage ratios as both microprudential and macroprudential measures. As such, it explains the role of the leverage cycle in causing financial instability and sheds light on the impact of leverage restraints on good bank governance and allocative efficiency.
\end{abstract}

Keywords: Leverage; Banks; Financial Instability; Macroprudential Regulation; Leverage Cycle; Bubbles; Debt Overhang

JEL Classifications: G21, G28, K22 


\section{INTRODUCTION}

Bank capital requirements are a key tool in regulators’ armory because bank capital can serve several key functions, including being used as a cushion for absorption of bank losses, as risk restraint, and as a market monitoring and discipline mechanism. ${ }^{1}$ On the basis of these assumptions bank failures should be a very rare phenomenon in the era of Basel Capital Accords. However, flawed capital structures were one of the most decisive factors in the string of bank failures we witnessed during the global financial crisis (GFC). Beyond the impact of high debt on creditor (including banking counterparties) confidence, excessive leverage influences shareholder preferences and bank manager behavior giving rise to socalled leverage agency costs. ${ }^{2}$

In general, there are three types of leverage: (i) "balance sheet," (ii) economic leverage, and (iii) embedded, respectively based on-balance-sheet concepts, marketdependent future cash flows, and market risk. ${ }^{3}$ Balance sheet leverage is the most recognized form as it is the most visible. It measures the ratio at which the value of a firm's assets exceeds its equity base. Banks typically leverage themselves by borrowing to acquire more assets, with the aim of increasing their return on equity. Economic leverage means that a bank is exposed to a change in the value of a position by an amount that exceeds what the bank paid for it. ${ }^{4}$ Finally, embedded leverage refers to holding a position that is itself leveraged. ${ }^{5}$ There is no single measure that can capture all three dimensions of leverage simultaneously. As a result, the EU Capital Requirements Regulation has provided a binding definition of what constitutes leverage, which firmly extends to balance sheet and economic leverage and catches embedded leverage only by implication and to the extent that measuring an institution's embedded leverage is possible. ${ }^{6}$

\footnotetext{
${ }^{1}$ Elliot (2010)

${ }^{2}$ A term I first coined in Avgouleas and Cullen (2015)

${ }^{3}$ D’Hulster (2009); also see European Banking Federation (2010, 4).

${ }^{4}$ A typical example is a loan guarantee, which is a contingent commitment that may materialize in the future but it does not presently appear in the balance sheet (D’Hulster 2009, 1-2).

${ }^{5}$ A simple example is a minority investment held by a bank in an equity fund that is itself funded by loans. While critical for the stability of the financial institutions and of the financial system, embedded leverage is extremely difficult to measure; see D'Hulster (2009, 2).

6 “(93) 'leverage’ means the relative size of an institution’s assets, off-balance sheet obligations and contingent obligations to pay or to deliver or to provide collateral, including obligations from received funding, made commitments, derivatives or repurchase agreements, but excluding obligations which can only be enforced during the liquidation of an institution, compared to that institution's own funds; (94) 'risk of excessive leverage' means the risk resulting from an institution's vulnerability due to leverage or contingent leverage that may require unintended corrective measures to its business plan, including distressed selling of assets which might result in losses or in valuation adjustments to its remaining assets.” On prudential requirements for credit institutions and investment firms and amending Regulation (EU) No 648/2012, OJ L 176/1, 27.6.2013, Art. 4. [Hereinafter CRR]. This official definition requires extensive
} 
Issues of definition and scope blighted earlier attempts to regulate banking via leverage ratios. The chief example was the US ratio, which totally failed to capture the perilous state of the US banks in the period before the collapse of Lehman Brothers in September 2008. The reason for that was that prior to the GFC, the US required its banks to report on a simplified leverage ratio, based on banks' Tier 1 capital ratio and their total on-balance-sheet risk-weighted assets (RWAs). ${ }^{7}$ As explained in section IV, below, banks engaging in a spate of assets substitution and securitizations could easily meet the Basel risk-weighted requirements, while they remained perilously leveraged. The proven ineffectiveness of leverage ratios that focused on on-balance-sheet exposures and the perceived superiority of risk weights as a measure of bank exposures meant that the earlier debate on bank leverage ratios was largely dismissive of their actual merits.

Today leverage ratios have made an impressive and largely unopposed return, mostly used alongside risk-weighted capital requirements. The reasons for this return are manifold and are not limited to the fact that banks equity levels in the wake of GFC were exceptionally thin, necessitating a string of costly bailouts. Four other factors have been as important. First is the world's revulsion with debt following the GFC and the eurozone crises as well as the debacle surrounding the debt ceiling of the US government. Secondly is the universal acceptance of Minsky's ideas about the nature of the financial system and its role in the real economy, ${ }^{8}$ especially when debt levels become unsustainable, triggering a chain of defaults. Third is the experience of the GFC, ensuing acceptance of Minsky's ideas, and related earlier research on the role of the financial sector as an agent of instability. This shifted regulatory attention from the level of the financial institution (so-called macroprudential regulation) to the level of the financial system (macroprudential regulation). This shift has guided a rich vein of socalled macroprudential thinking that is essentially studying the importance of the interaction of the credit channel with asset price levels, as well as the impact of macroeconomic developments on financial stability. This research has moved somewhat

clarification of how balance sheet and off-balance sheet exposures will be measured for the purpose of calculating a leverage ratio.

${ }^{7}$ Banks were rated on the "BOPEC” system (the condition of the BHC’s bank subsidiaries, other nonbank subsidiaries, parent company, earnings, and capital adequacy) to determine the level of capital required. Those banks that scored highly on this system were required to hold Tier 1 capital of 3 percent of RWAs, whilst those that scored poorly were required to hold 4 percent. These rules have since been updated. See "Risk-Based Capital Guidelines: Market Risk,” 77 Fed. Reg. 53,060 (Final Rule, Aug. 30, 2012) (12 C.F.R pts. 3, 208, 225, 325, 217, 324).

${ }^{8}$ For a restatement and a summary of the "financial instability hypothesis," see Minsky (1992). The original conception is described in Minsky (1970). Minsky built on earlier works on the role of debt by two famous twentieth-century economists. See Keynes (1936) and Fisher (1933). 
away from Minsky ${ }^{9}$ and the previous paradigm, which examined the impact of the credit channel on levels of economic activity, ${ }^{10}$ and it looks at the impact of the macroeconomy on financial stability. ${ }^{11}$ The best example of the causal link between excessive debt, asset bubbles, and financial instability was the Spanish and Irish banking crises, which were caused by nothing more sophisticated than straightforward bank loans to real estate developers who were riding the wave of gigantic real estate bubbles. ${ }^{12}$ The fourth and largely unspoken reason is that in an environment of excessive liquidity due to very low interest rates and quantitative easing (QE), leverage ratios are a key part of the macroprudential framework. Accordingly, leverage ratios are seen by their proponents not just as a microprudential measure intending to increase bank resilience but also as a way to decrease levels of indebtedness in the wider economy. This is especially the case under conditions of excessive liquidity, when the central bank cannot or is unwilling to use the monetary instrument, whether due to economic growth concerns or because of the uniformity of interest rates in a monetary union, or even due to flawed ideas about inflation measurement and growth.

This paper discusses leverage ratios as both a microprudential and macroprudential measure. As such it explores contemporary rationales and uses of leverage ratios in banking and explains the role of the leverage cycle in causing financial instability. It also sheds light on the impact of leverage restraints on good bank governance. In this context the paper also discusses some of the disadvantages of leverage ratios, as highlighted in earlier and contemporary academic and regulatory debate. Accordingly, the paper is divided in five sections in addition to the introduction. Section II explains the nature and impact of the leverage cycle and examines the drivers of excessive leverage in banking. Section III explains the adverse impact of excessive leverage on both financial stability and allocative efficiency. Section IV uses both a microprudential and a macroprudential perspective to shed light on some known and a number of novel ways (as identified by the author) in which leverage ratios augment financial stability. Section V considers the impact of bank leverage ratios on economic growth. Section VI offers an analysis of the contemporary framework for bank leverage ratios, especially as implemented in the UK, the US, and Canada. The final section concludes.

\footnotetext{
${ }^{9}$ Hellwig (2014)

${ }^{10}$ Kiyotaki and Moore (1997).

${ }^{11}$ E.g., Hellwig (2014).

${ }^{12}$ FitzGerald (2009); Dellepiane, Hardiman, and Las Heras (2013); Alcidi and Gros (2012).
} 


\section{THE LEVERAGE CYCLE AND DRIVERS OF EXCESSIVE LEVERAGE}

\section{A. The Leverage Cycle}

The dynamic feedback properties of leverage, volatility, and asset prices form the socalled leverage cycle. Market participants tend to behave in a procyclical fashion and the capacity to leverage balance sheets permits them to engage in greater speculation on asset prices than unleveraged investors, if speculation is the principal motive behind their decision to borrow and their equity losses in the event of a gamble going badly are lower-than-expected payoffs. ${ }^{13}$ The leverage cycle has been examined closely in recent years, especially in the post-2008 period. ${ }^{14}$ One of the most worrying characteristics of the leverage cycle is that while the risks it creates do seem Gaussian they can also give rise to fat tails. This means that planning a protection scheme against such rises may not always be viewed as a priority as they will probably be seen as negligible. Moreover as leverage is cyclical, so is the rise and fall of asset prices. ${ }^{15}$

Nonetheless, it is far from clear what triggers deleveraging. Namely, whether a fall in asset prices comes first followed afterwards by a fall in levels of new debt or vice versa. While the credit cycle should not be confused with the so-called "leverage cycle, ${ }^{, 16}$ the signature of the leverage cycle is also rising asset prices in tandem with rising levels of indebtedness, followed later by falling asset prices and deleveraging. The most important risk associated with leverage is the speed of deleveraging in a downturn. Thus, it may often prove difficult to prevent a "leverage cycle crash," ${ }^{17}$ which critically will lead to increased margin calls (so-called "margin calls spiral”) and probably to an evaporation of liquidity and a credit crunch. ${ }^{18}$ Accordingly, one of the most destabilizing effects of excessive leverage-for both individual financial institutions and the financial

\footnotetext{
${ }^{13}$ BCBS Basel III: A global regulatory framework for more resilient banks and banking systems (December 2010; revised June 2011). [Hereinafter Basel III].

${ }^{14}$ Fostel and Geanakoplos (2013). The authors have explained the cross-sectional implications of multiple leverage cycles, which invariably lead to contagion, flight to collateral, and swings in the issuance volume of the highest quality debt.

${ }^{15}$ Fostel and Geanakoplos (2013, 31).

16 "A Leverage Cycle is a feedback between asset prices and leverage, whereas a Credit Cycle is a feedback between asset prices and borrowing." Of course a leverage cycle always produces a credit cycle. But the opposite is not true. See Fostel and Geanakoplos (2013).

17 "Leverage cycle crashes always occur because of a coincidence of three factors. The bad news itself lowers the prices. But it also drastically reduces the wealth of the leveraged buyers, who were leveraged the most precisely because they are the most optimistic buyers. Thus the purchasing power of the most willing buyers is reduced. And most importantly, if the bad news also creates more uncertainty, then credit markets tighten and leverage will be reduced, just when the optimists would like to borrow more, making it much harder for the optimists and any potential new buyers to find funding." See Fostel and Geanakoplos $(2013,28)$.
}

${ }^{18}$ Brunnermeier and Pedersen (2009) 
system as a whole-is that it causes or inflates asset bubbles, due to a feedback effect on asset prices.

Intuitively, one would expect that in a fair-value environment a rise in asset prices would boost bank equity or net worth as a percentage of total assets. Stronger balance sheets would result in a lower leverage multiple. Conversely, in a downturn, asset prices and the net worth of the institution would fall and the leverage multiple would be likely to increase. ${ }^{19}$ Contrary to intuition, however, empirical evidence has shown that bank leverage rises during boom times and falls during downturns. Leverage tends to be procyclical because the expansion and contraction of bank balance sheets amplifies rather than contains the credit cycle.

Fostel and Geanakoplos (2013) explain that the reason for this phenomenon is that banks actively manage their leverage during the cycle using collateralized borrowing and lending. When monetary policy is "loose” relative to macroeconomic fundamentals, banks expand their balance sheets and, as a consequence, the supply of liquidity increases. In contrast, when monetary policy is "tight," banks contract their balance sheets, reducing the overall supply of liquidity. ${ }^{20}$ The explanation to some extent refutes the idea that mere extension of credit by fractional reserve banks (which is, to some extent, tantamount to creating private money) is the sole culprit and shows that loose monetary policy, especially QE, is similarly culpable. The same is the result of reinvestment of trade surpluses in the context of open markets, as it happened in the pre2008 period. $^{21}$

During periods of economic prosperity and low loan defaults, banks' capacity to create credit, coupled with inflated collateral values, increases banks' capital reserves and removes constraints on further credit growth. ${ }^{22}$ In addition, some financial assets become very popular amongst a certain class of buyers in relation to the rest of the public. ${ }^{23}$ Buyers in this case are willing to pay higher prices, or tolerate increased risk. ${ }^{24}$ This is often due to optimistic expectations concerning the future price trajectory of a given set of assets. Unsurprisingly, such procyclicality contributes to higher risk-taking

\footnotetext{
${ }^{19}$ See D’Hulster (2009)

${ }^{20}$ Shin and Adrian (2008)

${ }^{21}$ See Caballero and Krishnamurthy (2009); see also Borio and Lowe (2002).

${ }^{22}$ Turner (2010)

${ }^{23}$ Geanakoplos (2010b, 1-65)

${ }^{24}$ Albertazzi and Gambacorta (2009, 393-409)
} 
by banks ${ }^{25}$ and influences bank managers’ behavior, ${ }^{26}$ especially where an important component of the compensation package is variable. ${ }^{27}$

\section{B. Drivers of Bank Leverage}

A debt-financed corporation is, in principle, as efficiently funded as an equity-financed one. ${ }^{28}$ But, in reality, bank capital structures are a function of the relative costs of capital. ${ }^{29}$ Invariably, the costs of raising equity capital exceed those in relation to raising debt finance, as equity capital is perceived to be riskier than debt. ${ }^{30}$ In addition, debt finance enjoys a more favorable tax treatment, as interest payments are deducted from tax liabilities whereas dividends are taxed as income. In the absence of a bail-in risk, or when depositors and senior debt holders are exempted from bail-in, bank creditors are exposed to a much lower level of risk than the aggregate risk level of the entire pool of bank assets, and thereby receive much lower returns. In contrast, bank equity holders are exposed to much greater risks and therefore receive higher returns on investment. Increased equity requirements will therefore, in general, increase the costs of capital. ${ }^{31}$ So the first driver of bank leverage relates to relative costs of financing balance sheet expansion and that's regardless of the documented too-big-to-fail subsidy that may diminish with the influx of bail-in regimes. ${ }^{32}$

While cost of funding is a fundamental factor behind bank leverage levels, this cost is not merely a matter of preferential tax treatment. Debt cost advantages also relate to macroeconomic conditions prevalent at particular points in the business cycle. If the costs of borrowing are artificially low, due to prevailing national and global conditions of excessive liquidity, extensively insured deposits, or because of quantitative easing,

\footnotetext{
${ }^{25}$ Laeven and Levine (2009, 259); Chen, Steiner, and Whyte (2006, 30); Saunders et al. (1990, 643)

${ }^{26}$ Avgouleas and Cullen (2015)

27 " [I]n benign markets with no recent history of negative events managers will potentially take high risks, as they essentially underestimate low-probability, high-risk events [...] The reward structures currently observed in the banking and investment industry can play their part in cyclical risk taking because they exacerbate the short-term focus and provide incentives for disaster myopia.” (Financial Services Authority 2009, 4.24-4.27)

${ }^{28}$ See Modigliani and Miller (1958).

${ }^{29}$ The non-conformity in risk between bank debt and bank equity is, of course, compounded by the fact that debt instruments are afforded generous tax treatment; see Stone $(1967,42)$.

${ }^{30}$ Furthermore, if a bank is forced to raise funds externally, its shareholders will prefer the raising of debt to equity, as any increase in equity funding will dilute their shareholdings. This largely refutes the "capital structure irrelevance principle” first proposed by Modigliani and Miller (1958).

${ }^{31}$ For a rejoinder to this argument, see Admati et al. (2011/rev. 2013).

${ }^{32}$ On this issue, see Avgouleas and Goodhart (2015).
} 
this will result in severe distortions in bank funding preferences, even in the absence of tax subsidies. ${ }^{33}$

Moreover, even where a possible realignment of tax regimes and credible threats of creditor bail-ins end up eliminating the too-big-to-fail subsidy, prevalence of very low interest rates and of attendant excessive liquidity makes debt funding more attractive, ${ }^{34}$ incentivizing increased use of uninsured debt to fund bank assets. ${ }^{35}$ Excessive liquidity leads to a generalized underpricing of risk testing to its limits creditor discipline, as they chase higher yields in an artificially low interest rate environment. In addition, banks focusing on return on equity (RoE) will feel obliged to exploit this underpricing of risk to leverage and expand their balance sheet to increase profitability. ${ }^{36}$

The relative riskiness of bank asset portfolios is driven largely by the preferences of the category of each agent class (deposit guarantor, shareholder, or manager) that dominates bank decision making. Based on this classification, banks, which are dominated by shareholder decision making, favor the highest level of risk, followed by manager-dominated banks and, lastly, by banks dominated by depositguarantors. To the extent therefore that capital requirements may influence bank behavior, governance arrangements in those institutions will inevitably be affected. ${ }^{37}$ It follows that shareholder-dominated banks will, in the absence of leverage constraints, pile up leverage: shareholders have a clear conflict of interests when choosing a bank's capital structure and they normally prefer to finance balance sheet expansion through debt. ${ }^{38}$ Admati et al. (2014) have vividly explained the reasons for shareholders' persistent preference of high leverage. ${ }^{39}$ While premature debt redemption in good times favors creditors as the bank will become safer and less likely to fail in bad times, therefore lowering creditor risks, bondholders will inevitably ask to hand in their bonds to be redeemed for a price higher than the prevailing market price. Thus, early redemption will eat into bank profits leaving shareholders worse off without any clear compensating benefit on the share price that might even decline as lower leverage clearly points to lower levels of future profitability. This makes the upfront cost of early

\footnotetext{
${ }^{33}$ Keeley and Furlong (1990)

${ }^{34}$ Shleifer and Vishny (1992)

${ }^{35}$ Diamond and Rajan (2001)

${ }^{36}$ Shareholder preference for debt is independent of any too-big-to-fail subsidies in Admati et al. (2012) model and this assumption is pretty sound.

${ }^{37}$ See Jeitschko and Jeung (2005). These results are robust when adjusted for incomplete asset markets, limited liability, and shareholder-value-maximizing banks; see Rochet (1992)

${ }^{38}$ Admati et al. (2014)

${ }^{39}$ Admati et al. (2014)
} 
tax redemption undesirable to shareholders. However, this shareholder preference for high leverage may have a so-called "ratchet effect" whereby worthy projects are ignored by an over-leveraged bank in favor of lower quality loans. ${ }^{40}$ It follows that in the absence of controls on leverage, all that was required, even in the case of benign senior managers, was to imitate competitor business strategies and herd.

At the same, bank management may use asset substitution to shift risks, a process made much easier through leverage, ${ }^{41}$ especially where capital regulations allow/foster this process. The possibility of regulatory arbitrage may mean that banks select asset portfolios with higher risk in order to maximize return on capital. ${ }^{42}$ Risk weighting of assets in bank portfolios ought to mitigate these effects somewhat, assuming that risk weights were accurate, ${ }^{43}$ in the absence of asset substitution. But it is clear that banks push many risks off balance sheet and actively manage risk weights. ${ }^{44}$ This process has been made much easier in the past thirty years, thanks to excessive use of financial innovation and permitted agglomeration of banking and trading books. I discuss the impact of permitted risk-weight optimization on bank capital structures in section IV.A, below.

Conglomeration and the ability to hide risk or losses also play a key role in the choice of bank capital structures, although there is a dual causality here, since size also rendered banks immune to failure. ${ }^{45}$ In general, financial innovation and the ability to “optimize” capital structure through leverage were key factors behind the growth of mega-banks in the 2000s. In the case of transactional banking, leverage can be the catalyst for rapid building of bank asset size. ${ }^{46}$ But, as leverage reduced the impact of trading positions on cash flows, it enabled banks to reduce the amount paid from the outset, upon conclusion of a financial contract, particularly when derivatives are used. ${ }^{47}$ Financial innovation allowed financial institutions to trade in notional amounts and leverage their trading positions on the basis of thin margins or borrowed collateral. This fueled the expansion of trading book and (to a lesser extent) lending book assets, on the basis of a thin capital base. These techniques increased risk-taking not only because there was no obvious limit to the kind and size of financial bets a bank could take but

\footnotetext{
${ }^{40}$ Admati et al. (2014)

${ }^{41}$ Acharya, Mehran, and Thakor (2010)

${ }^{42}$ Kahane (1977); Koehn and Santomero (1980)

${ }^{43}$ Bradley, Wambeke, and Whidbee (1991); Kim and Santomero (1988)

${ }^{44}$ Discussed in detail in part IV; see Goodhart (2011).

${ }^{45}$ Avgouleas (2009)

${ }^{46}$ Boot (2001); Boot and Thakor (2000)

${ }^{47}$ Blundell-Wignall and Atkinson (2012)
} 
also because trading positions are easy to bury in a big bank's balance sheet-a possible explanation for financial industry's lobbying towards conglomeration in the 1990s. ${ }^{48}$

Finally, because leveraged institutions are also likely to be more opaque, evaluating the riskiness of their operations may be difficult. Banks' ability to borrow heavily to alter financial risks permits them to engage in asset substitution more readily than non-financial firms, ${ }^{49}$ and hide problems in their asset books. ${ }^{50}$ In the presence of significant managerial incentives to adopt a leveraged capital structure, the ease with which risks are shifted increases incentives for banks to grow their balance sheets. ${ }^{51}$

\section{THE ADVERSE IMPACT OF EXCESSIVE LEVERAGE ON FINANCIAL STABILITY AND ALLOCATIVE EFFICIENCY}

\section{A. Impact on Financial Stability}

Banks facilitate greater leverage amongst non-financial companies, yet they are also highly leveraged themselves, increasing the probability of risks arising from debt contracts. ${ }^{52}$ Leverage exacerbates the danger of contagion in the banking system and exacerbates the transmission of risks from the financial system to the real economy for a number of reasons. First, in giving rise to credit and asset price cycles, excessive leverage contributes to macroeconomic booms and busts, ${ }^{53}$ so-called asset bubbles ${ }^{54}$ and crashes. ${ }^{55}$ Driven as they are by flawed assumptions concerning fundamental value or by competitive pressures, bubbles have the potential to cause serious economic damage once they burst. It is clear that leverage increases in boom years when banks finance riskier loans, and recedes during periods of economic contraction. ${ }^{56}$ Thus, in periods of market booms, as asset markets typically become inflated, investors’ appetite for risk

\footnotetext{
${ }^{48}$ This part of the paper draws on Avgouleas (2015).

${ }^{49}$ Merton (1977)

${ }^{50}$ Levine (2004); Myers and Rajan (1998)

${ }^{51}$ Morgan (2002)

52 Turner (2010)

${ }^{53}$ Geanakoplos (2010a)

54 "Bubbles" are a ubiquitous phenomenon in modern capitalist development. The bubble taxonomy has been described as: "The process is characterised by competitive herd behaviour which ... produce[s] widespread and gross asset mispricing which [is] eventually and dramatically corrected.” See Kay (2001). For a detailed description and explanation of the many bubbles to afflicted asset markets throughout history see Kindleberger and Aliber (2005).

${ }^{55}$ Adrian and Shin (2010)

${ }^{56}$ Delis, Tran, Tsionas (2011)
} 
and speculation is amplified. Asset price growth at these higher rates, however, may be "incompatible with the potential for overall, real economic expansion." 57

Secondly, as already noted, leverage contributes to procyclicality because of the compound effect that increased borrowing may have on asset prices. It follows that the negative effects of leverage are felt more keenly in times of general financial distress. ${ }^{58}$ Investors are aware that the capital reserves of highly-levered institutions will be wiped out in the event of negligible asset price falls. ${ }^{59}$ Thus, in a downturn, a bank with a highly levered balance sheet will suffer loss of confidence much earlier and faster than less-leveraged institutions. This leaves the financial system vulnerable to episodes of market panic, where asset price deflation and fire sales can quickly lead to mass insolvencies. $^{60}$

Moreover, even where insolvency is not an immediate threat, potential regulatory initiatives asking highly levered banks to sell assets to bolster capital in the event of distress could inadvertently create problems for other financial institutions. The decision to sell assets is likely to lead to downward pressure on asset prices. This can give rise to a market shock, or exacerbate one in the event of systemic disruption, when the entire banking sector is forced to deleverage. ${ }^{61}$ For example, collateralized debt contracts with margin calls (ubiquitous in bank trading), if leveraged, increase fat tail distributions and clustered volatility. ${ }^{62}$ These distributions, when coupled with the effect of any repricing of collateral, exacerbate downward price spirals. The damage inflicted by deleveraging phases on both the financial system and the real economy is often significant, ${ }^{63}$ and where borrowing levels have risen to unsustainable levels, it may lead to GDP reduction, negating the growth gains initially made due to high leverage.

\section{B. Allocative Efficiency Impact}

Apart from an adverse impact on financial stability, the most significant drawback of excessive leverage is so-called "debt overhang," which reduces the efficiency of bank lending. It prevents firms from borrowing (and banks from lending) money to finance

\footnotetext{
${ }^{57}$ Delis, Tran, Tsionas (2011)

${ }^{58}$ Shleifer and Vishny (2011)

${ }^{59}$ If a bank loses $\$ 1$ million and equity capital stands at 3 percent of its balance sheet, then the bank attempting to deleverage must liquidate more than $\$ 33$ million worth of assets just to maintain that 3 percent ratio.

${ }^{60}$ Gennaioli, Shleifer, and Vishny (2010)

${ }^{61}$ Adrian and Shin (2010)

${ }^{62}$ Thurner, Farmer, and Geanakoplos (2010)

${ }^{63}$ BCBS (2011, 69 and 189)
} 
investment, even where that investment is guaranteed to produce a return, because of the earlier excessive borrowing and resulting fragile capital structures. Firms with large debt-equity ratios will therefore pass up valuable investment opportunities, even where those opportunities would lead to an increase of the firm's net value. Where bank capital falls (for example, due to asset repricing) it will prove extremely difficult for a bank to escape debt overhang and worthwhile investments will be sacrificed in favor of asset sales and deleveraging.

In these circumstances, if regulators require a replenishment of the bank's capital base, the bank will be unable, or unwilling, to extend credit to worthwhile borrowers. This, by implication, reduces the overall volume of funding available to finance projects and creates inefficiencies in the allocation of funds. Thus, highly levered banks eventually make less efficient investment decisions ${ }^{64}$ resulting in both underinvestment due to the debt overhang ${ }^{65}$ and misallocation of resources. Accordingly, overborrowing (and investment) during boom times is followed by a serious halt on new investment during a downturn triggering a liquidity asphyxia and of course a sharp correction/fall in asset prices. ${ }^{66}$ Both developments tend to have chain effects on economic activity and employment rates as well on savings ratios.

\section{THE BANK LEVERAGE RATIOS AND CAPITAL REGULATIONS: A MICRO- AND MACROPRUDENTIAL PERSPECTIVE}

\section{A. Bank Leverage Ratios: A Microprudential Perspective}

\section{i. Adverse selection}

There is evidence that leverage restrictions may not reduce risk. Even if the risk of individual assets remains constant, bank managers may be incentivized into choosing assets with more highly correlated returns. ${ }^{67}$ Accordingly, as this argument goes leverage ratios may encourage banks to increase the riskiness of their asset portfolio not decrease it, a classic Goodhart's Law outcome. In the view of many this concern was precisely the rationale for seeking risk sensitivity in the Basel framework in the first place. ${ }^{68}$ In many ways reluctance to regulate leverage stemmed from a fear that it would affect economic growth without making banks safer, since banks would evade the "crippling” profit

\footnotetext{
${ }^{64}$ See Hanson, Kashyap, and Stein (2011); Stein (2011).

${ }^{65}$ Myers (1977)

${ }^{66}$ See also Occhino and Pescatori (2010).

${ }^{67}$ Gale (2010)

${ }^{68}$ See, in general, Schoenmaker (2014).
} 
consequence of a strict leverage ratio by focusing on high-return projects, which are riskier in most cases. Namely, as this argument goes, leverage ratios are bound to create perverse incentives. ${ }^{69}$ The fact that leverage ratios do not distinguish between different types of bank assets on the basis of their riskiness could mean that banks felt encouraged to build up relatively riskier balance sheets or to expand their off-balance-sheet activity. ${ }^{70}$ In addition, the lack of risk weighting in the calculation of leverage ratios could penalize prudent banks holding substantial portfolios of highly liquid, high-quality assets.

Nonetheless, for a ring-fenced or Volcker-separated bank the room for repositioning its balance sheet to assume riskier assets is drastically limited, perhaps unduly so. Therefore, this risk for ring-fenced or Volcker-separated banks is rather exaggerated. Moreover, by eliminating the agency costs excessive leverage generates by virtue of this effect on senior executive behavior and the "ratchet" effect, discussed by Admati et al. (2014), ${ }^{71}$ whereby worthy projects are ignored by an over-leveraged bank in favor of lower quality loan, ${ }^{72} \mathrm{a}$ leverage ratio is more likely to improve rather than deteriorate the quality and riskiness of bank loans. Moreover, given the number of other restrictions imposed on the formal banking sector post-2008, it is possible that instead of a shift to riskier assets banks would focus on extracting a premium from their existing customer relationships leading to marked improvement of their customer services and banking products.

\section{ii. Basel I \& II risk-weighted asset ratios and regulatory arbitrage: a license to} leverage?

Well-calibrated bank capital requirements should be able to both prevent banks from assuming excessive risk and compel banks to build sufficient capital cushions to absorb losses. Yet this is not what our recent experience says. At the heart of the GFC were severely under-capitalized banks. The main mechanism through which additional leverage became embedded within the financial system involved asset substitution by banks to circumvent capital requirements. This process led to capital structure reporting that was misleading. Whilst asset levels increased markedly in the years leading up to the GFC, reported leverage

\footnotetext{
${ }^{69}$ D’Hulster $(2009,4)$

${ }^{70}$ D'Hulster (2009)

${ }^{71}$ Inefficient increases in leverage resemble risk-shifting problems, where shareholders take an action for their own benefit that harms existing creditors. See Admati et al. (2014).

${ }^{72}$ Admati et al. (2014)
} 
levels at large commercial banks were remarkably constant. ${ }^{73}$ This would normally suggest that, whilst banks expanded asset levels aggressively, they also managed to maintain stable regulatory capital levels and leverage ratios. Of course, official data did not provide the full picture. Leverage increases were caused by poorly calibrated internal financial models, ${ }^{74}$ the abysmal performance of credit rating agencies, ${ }^{75}$ and fraud. ${ }^{76}$ Moreover, there is strong evidence that reported leverage levels at both commercial and investment banks were manipulated, or were inaccurate, due to exploitation of applicable rules on bank capital by senior bank management. ${ }^{77}$

A good example of how banks engaged in "risk-weight optimization" (RWO) is offered by the increased role of complex securitized credit and marketable securities, which provided additional avenues to augment bank capital structures. ${ }^{78}$ Under the Basel I and II Accords, the lower risk weights that securitized products attracted meant that banks did not have to hold the same levels of capital, as would be the case if the underlying products were not securitized. An authoritative OECD study has demonstrated that mega-banks used their internal-ratings-based (IRB) approach to the Basel Accords to manage RWAs in a manner that allows banks to comply with higher capital requirements with very small increases in the proportion of common equity. This has resulted in several large European banks being financed with very low levels of common equity, despite being “well-capitalized” in terms of Tier 1 risk-based capital. In fact, this pattern is replicated, to a certain extent, by US mega-banks. ${ }^{79}$ Interestingly enough, more recent research confirms that RWO has not abated since the GFC. ${ }^{80}$

Much RWO was achieved through employment of securitization models, as it was assumed that by diversifying and spreading risk throughout the financial system through securitization, the financial system would be more stable and more resilient to shocks. ${ }^{81}$ However, much of the credit risk remained in the banking system, as some of

\footnotetext{
${ }^{73}$ For example, reported commercial bank leverage was largely unchanged between 2000 and 2009; see Kalemli-Ozcan et al. (2012).

${ }^{74}$ Simkovic (2009)

${ }^{75}$ Hunt (2009)

${ }^{76}$ For example, it was documented by the lead counsel in the Lehman Brothers bankruptcy case that Lehman systematically attempted to conceal its true leverage ratio by using accounting techniques to remove liabilities from the core bank to its SIVs. This allowed Lehman to build up unreported leverage and remove debt from its balance sheet, "to create a materially misleading picture of the firm's financial condition in late 2007 and 2008...” See US Bankruptcy Court of the District of New York (2010)

${ }^{77}$ For detailed discussion see infra.

${ }^{78}$ The securitization process may be used to convert lower-grade individual financial products into highergrade securities; see Stein (2010).

${ }^{79}$ Norton (2013)

${ }^{80}$ Blundell-Wignall and Atkinson (2012)

${ }^{81}$ See also on this Wachter (2015).
} 
the most active purchasers of structured financial products were banks themselves: approximately 50 percent of asset-backed AAA-securities remaining within the banking system were merely adding to total bank leverage. ${ }^{82}$ In addition, benefiting from the manipulation of capital regulations, banks switched away from loans into structured financial products, which attracted higher capital relief.

In the period leading up to the GFC, RWO was practiced by all banks, e.g., Northern Rock, not just the larger banks that enjoyed the too-big-to-fail subsidy. Essentially, banks funded a large amount of their assets with short-term liabilities ${ }^{83}$ through the use of conduits and off-balance-sheet vehicles. ${ }^{84}$ These conduits raised funds by selling short-term assetbacked commercial paper, with the assets concerned usually comprising mortgage pools and secured loans. ${ }^{85}$ Because these conduits funded themselves with short-term debt, any loss of confidence or liquidity pressures due to a reduction in buyers of commercial paper would quickly destroy their viability, indirectly exposing the sponsor bank to funding liquidity risk. To offset this risk, banks granted credit facilities and guarantees to their conduits; however sponsor banks remained liable for any losses arising from the conduit.

These risks were attenuated by the increasing maturity mismatch on the balance sheet of investment banks, which funded many of their operations through repurchase agreements (“repos”). According to estimates, investment bank repo financing doubled between 2000 and 2007 and in this way it exposed the investment banks to potential liquidity shortfalls, if repo financing became compromised. ${ }^{86}$ Large banks also enjoyed privileged access to these supplies of short-term debt over and above their access to depositor finance, so they were presumed to be safe in the event of a liquidity crisis. In practice very few large banks were able to raise funds to bolster their capital once the GFC unfolded. In 2007 the short-term debt market collapsed ${ }^{87}$ ruining the solvency of many institutions, which were found to be severely undercapitalized. ${ }^{88}$

\footnotetext{
${ }^{82}$ Acharya, Schnabl, and Suarez (2010)

${ }^{83}$ In theory, short-term debt can enforce market discipline through the threat of withdrawal of funding; see Calomiris and Kahn (1991).

${ }^{84}$ US depository institutions increasingly funded their total assets by borrowing in short-term debt markets. In the 1960s, approximately 2 percent of US banks' balance sheets were funded in these markets and by 2008 this had reached 22 percent; see Blair (2013).

${ }^{85}$ See Financial Services Authority (2009).

${ }^{86}$ Brunnermeier (2009)

${ }^{87}$ Gorton and Metrick (2012)

${ }^{88}$ For example, in 2007 Citigroup was responsible for 25 percent of the market in SIVs. Its biggest SIV, Centauri, had lent out $\$ 21$ billion before the credit crunch. It was not included in the consolidated accounts of Citigroup plc in 2006. Citigroup announced write-downs in 2008 of approximately $\$ 41$ billion. See IMF (2008, 67-68, fig. 2.2); see also Acharya and Richardson (2009).
} 
One of the key reasons for this perverse, at first glance, behavior was that credit lines to conduits were subject to less than 20 percent capital requirements than were required against on-balance-sheet assets, provided that such lines had a term of less than a year. ${ }^{89}$ Thus, most banks extended credit lines to conduits that had duration of 364 days or less and did not retain capital buffers with which to withstand heavy losses from conduits. ${ }^{90}$ By 2007, commercial banks' off-balance-sheet vehicles had total assets of \$2.2 trillion, more than the assets of hedge funds (\$1.8 trillion) and more than half of the total of the five largest investment banks ( $\$ 4$ trillion). ${ }^{91}$ However, these conduits exposed sponsor banks to identical risks as those related to on-balance-sheet financing. These banks suffered the greatest losses and lost most in equity valuation during the GFC. ${ }^{92}$

Admittedly, the new Basel III liquidity requirements go a long way to at least curb this perverse reliance on short-term funding. Yet there are additional arguments mitigating in favor of introduction of leverage ratios from a microprudential perspective. First, the Basel system of risk weights has also been criticized as excessively complex and highly difficult to understand, rendering it ineffective as a source of market discipline, also given its susceptibility to gaming. In fact, investors have reported losses of confidence in the risk-weighting system ${ }^{93}$ and in the capacity of banks to calculate their levels of RWAs, even amongst specific asset classes. ${ }^{94}$ Reported wide discrepancies in British banks' capital ratios when non-weighted assets are measured against own funds ${ }^{95}$ provide enough evidence to make any confident investor in the banking sector and prudent bank regulator lose sleep. ${ }^{96}$ This uncertainty severely

\footnotetext{
${ }^{89}$ See Brunnermeier (2009, 80-81); see also Acharya and Schnabl (2009).

${ }^{90}$ IMF (2008)

${ }^{91}$ Tett (2009)

${ }^{92}$ Acharya and Schnabl (2009)

${ }^{93}$ Bailey (2013); Barclays Equity Research (2012a)

${ }^{94}$ Barclays Equity Research (2012b)

${ }^{95}$ For example, Standard Chartered had the strongest Core Equity Tier 1 capital to RWAs ratio at 9.8 percent. Stripping away risk weighting left it with an unweighted leverage ratio of 4.3 percent. However, many UK banks are not so well capitalized. Barclays, for example, reported Core Equity Tier 1 capital of 8.5 percent, but its unweighted leverage ratio was 2.9 percent. Lloyds Banking Group and RBS each had unweighted leverage ratios of 3.1 percent, against Core Equity Tier 1 capital to RWAs ratios of 8.2 percent and 6.5 percent, respectively. Indeed, the UK Prudential Regulation Authority has stated that UK banks have a collective capital shortfall of $£ 13.7$ billion. See "News Release-Prudential Regulation Authority (PRA) completes capital shortfall exercise with major UK banks and building societies,” available at: <http://www.bankofengland.co.uk/publications/Pages/news/2013/081.aspx>.

96 This is how the Financial Times has reported these discrepancies: “The UK's five biggest banks are considered among the best capitalized in Europe on the traditional measure of core tier one equity divided by risk-weighted assets ... The ratios range from 12.3 per cent at HSBC down to 10.3 per cent at Royal Bank of Scotland. The disclosed leverage ratios strip out the effect of risk modelling, which has the effect of more than doubling the size of every bank’s balance sheet and more than tripling that of Barclays...
} 
undermines rather than reinforces market discipline.

Secondly, there is remarkable inconsistency in the way bank models measure RWA risk. The best recent example is the more favorable rating that credit rating agencies give to derivatives exposures of banks over bank debt, due to the preferential treatment of derivatives contracts under the EU and, to some extent, the US resolution regimes. To this effect, research by the BCBS confirms considerable variation across banks in the reporting of risk-based measurement of assets. ${ }^{97}$ Whilst some degree of variation may be due to differences in the composition of trading assets, there are also significant difficulties in comparing banks from separate regulatory jurisdictions. ${ }^{98}$ For instance, there is a considerable degree of variation in, inter alia, the market-risk measurement methodologies employed by global banks, banks' modeling choices, on the basis of the Basel II internal ratings methodology (retained by Basel III), and accounting requirements and practices. ${ }^{99}$ Most of these variations may be explained by the fact that banks are able to "use whatever models they like, provided supervisors sign off on basic rules of their use. The same [product] therefore may be priced differently in two different banks. ${ }^{, 100}$ In the event of a crisis all this hardwired uncertainty as to the true state of bank capital reserves will lead to a near certain loss of confidence in the banking system $^{101}$ and at the very least to an investor flight from bank shares, as it happened during the GFC. ${ }^{102}$

Thirdly, there is a growing body of empirical evidence that suggests that RWAs are not a significant indicator of the possibility of bank default. As mentioned earlier, in the simplest form of gaming the rules, banks turned high-risk credits into highly rated structured securities eliminating capital requirements although they extended credit lines to requisite securitization vehicles, which attracted no capital charges. Yet, provision of

[The] unvarnished look at each bank's borrowing produces far different results. As of December 31, Standard Chartered had the strongest ratio at 4.5 per cent, meaning that it has assets equal to 22 times its capital. Barclays has the weakest, with 2.8 per cent. That means Barclays had assets worth more than 35 times its capital base.” (Masters 2013)

${ }^{97}$ BCBS (2013)

${ }^{98}$ In the US, the federal agencies themselves used to apply different rules to RWAs. Those responsible for regulating ratings have recently proposed a rule to revise and harmonize the agencies' rules for calculating RWAs to enhance risk sensitivity and address weaknesses identified over recent years, including by incorporating certain international capital standards of the Basel Committee on Banking Supervision (BCBS); see Federal Register (2012).

${ }^{99}$ See Ingves $(2013,6)$.

${ }^{100}$ Blundell-Wignall and Atkinson, (2011). These variations are surely intolerable in an era of global banking.

${ }^{101}$ As noted by Laurence Kotlikoff: "When trust takes a holiday, creditors find no comfort in capital ratios ... banks' opacity makes it impossible to verify if their capital ratios are as high as advertised." See Kotlikoff (2012, 27).

${ }^{102}$ See on this Avgouleas (2011, 71-110). 
liquidity facilities to these vehicles exposed them to appreciable risks in the event of disruption of payments to the SPV by the original borrowers, e.g., due to a disruption in borrower households' income. Moreover, they held structured credit instruments on their own balance sheet, exposing themselves to embedded leverage and increasing their asset-liability mismatch and their funding liquidity risk.

OECD has found that Basel Tier 1 capital levels were not a statistically significant predictor of default risk. When analyzed on the basis of unweighted leverage ratios, however, a significant statistical link was present. ${ }^{103}$ As noted by the authors of the study a simple leverage ratio is a much better predictor of default risk than RWA measures, which are invariably subjected to RWO. ${ }^{104}$ In the same mode, Andy Haldane of the Bank of England has put together a persuasive set of tables showing that leverage has been a better predictor of bank survival than capital. ${ }^{105}$

Here it should be noted that, as already mentioned, while the US had a leverage ratio as a prudential tool, it failed to give any warning signs; as a result US banks were at the center of the GFC. Nonetheless, in this case it was the ratio's inability to catch off-balancesheet exposures in a period that US banks were massively engaged in off-balance-sheet activity. As a result, the leverage ratio did not produce any warning signs. This means that the way the leverage ratio is calculated and how off-balance-sheet exposures are accounted for as part of bank assets is a process as important as identifying the right ratio.

\section{iii. Governance Benefits}

As I have argued elsewhere, the issue of managerial incentives at banks is heavily intertwined with the overarching issue of bank leverage. ${ }^{106}$ The reason for this is quite simple and in accord with fundamental assumptions of classical corporate governance about alignment of managers' and owners' incentives. The portfolio preferences of the class of agent with most influence over bank investment strategies and loan direction (the class of agents being deposit-guarantor, manager, or shareholder) is of fundamental importance. At one end of the scale—-banks dominated by deposit guarantors — the banks concerned will favor low levels of leverage because of the incentives they have to minimize the cost of bank failures to the insurance system, even if this results in suboptimal debt levels from the

\footnotetext{
${ }^{103}$ See Blundell-Wignall and Roulet (2013). For this study, the OECD examined a sample of 94 US and EU internationally active commercial banks and broker dealers with market capitalizations of over \$5 billion, over the period 2004-11.

${ }^{104}$ Blundell-Wignall and Roulet $(2013,16)$

${ }^{105}$ Haldane and Madouros $(2012,14)$

${ }^{106}$ Avgouleas and Cullen (2015)
} 
viewpoint of efficiency. On this basis, regulatory provisions to manage bank capital levels indirectly affect the asset choice of the bank. ${ }^{107}$ Manager-dominated banks will generally target a higher level of risk than those run in the interests of deposit guarantors, although they would not wish to run excessive risks relative to shareholders due to two main considerations: (i) once a bank fails it loses its charter value, retention of which is the primary incentive for managers as the source of their private benefits; ${ }^{108}$ and (ii) their interests, unlike those of shareholders, are generally non-diversifiable. Accordingly, corporate governance arrangements, which have as their purpose to incentivize managers to act like shareholders may have pronounced effects on bank risk-taking and leverage.

Clearly, where managerial rewards are contingent on shareholder returns, this naturally places limits on analyzing shareholders and managers as distinct stakeholder groups within banks. Senior managers are often subject to pressure to assume risk from both shareholders, who would wish to increase their profit, and from peer institutions' management who may take risks in order to compete more aggressively. Managers are incentivized to act in the financial interests of shareholders, especially via their compensation awards, and may be dismissed by shareholder-appointed boards, if the risk appetite of bank owners is not being satisfied; arguably there is a thin dividing line between the interests of owners and managers, which in the light of shareholders' capital structure preferences, will influence management decision making. Moreover, the above distinction may not be as clear cut as it used to be prior to the 2008 bailouts, especially in the UK where a large portion of the banking sector has been nationalized, thereby fusing depositguarantors and shareholders (although not necessarily their interests). Interesting questions that arise therefore relate to the various risk tolerances in the contemporary UK banking sector, and what effect those tolerances may have on financial stability.

Shareholders have a clear conflict of interest in deciding upon a bank’s capital structure because of the relative non-concavity of their risk-reward position: under current legal provisions, shareholders stand to gain most and lose least from leveraging their capital, through reducing their "skin in the game," and gambling with creditors' money as far as possible. ${ }^{109}$ These factors will lead an equity value-maximizing shareholder to pursue excessive risk-including increased leverage. ${ }^{110}$ Normally, shareholders prefer to hold the least amount of capital permitted by bank regulations because of the opportunity cost of

\footnotetext{
107 Jeitschko and Jeung (2005)

${ }^{108}$ Gale (2010)

${ }^{109}$ Admati et al. (2014)

${ }^{110}$ Sharpe (1978)
} 
retaining earnings, and it will be unlikely that market discipline will operate to prevent risk weights being manipulated, especially due to imperfect shareholder monitoring and managerial career concerns. ${ }^{111}$

Two of the key determinants of the stock price of a corporation are its earnings per share and the expected future growth rate of those earnings. More highly leveraged corporations earn higher RoE even where they are equally efficient in achieving returns on those assets. Evidence from UK banks is indicative: RoE increased from single figures in the beginning of the twentieth century to approximately 20 percent by the end of that century. Right before the GFC, leverage had increased to around 30 percent. Haldane argues that virtually all of these returns may be explained by increased leverage. ${ }^{112}$ The focus placed in the banking sector on achieving high RoE, most obviously designed to attract and maintain investors, is also strongly linked to bankers’ compensation schemes, which, in rewarding superior RoE implicitly encourage higher leverage. This is particularly true in the absence of employee sanctions for failure including compensation clawback provisions (e.g., Section 954 of the Dodd-Frank Act; SEC Proposed Rule, 2015).

Furthermore, because leverage will amplify gains from both risky and riskless investments, and riskier assets generate higher returns, RoE targets incentivize asset risk. ${ }^{113}$ Research on bank performance during the GFC strongly suggests that asset write-downs were positively and significantly related to asset volatility and leverage. ${ }^{114}$ The natural shorttermism of most large shareholders-who on average hold their shares for a matter of months_-results in incentives for managers to adopt short-term investment horizons even where meeting the relevant targets results in excess risk. ${ }^{115}$ On the other hand, even smaller shareholders with longer horizons-perhaps more eager to exercise their monitoring function-will face the natural boundary of complexity. ${ }^{116}$ The importance of these factors was arguably evidenced in the GFC, in which banks with relatively high equity and performance-based compensation lost the most value. ${ }^{117}$ In addition to profitability rates, more levered institutions may expand more quickly to capture market share, which in competitive markets provides incentives to assume greater leverage levels.

\footnotetext{
${ }^{111}$ Avgouleas and Cullen (2014)

112 Haldane (2011)

${ }^{113}$ Smith and Stulz (1985)

${ }^{114}$ Chesney, Stromberg, and Wagner (2011)

115 See Graham, Harvey, and Rajgopal (2015)

${ }^{116}$ Avgouleas and Cullen (2014)

${ }^{117}$ Bebchuk, Cohen, and Spamann (2010); Chesney, Stromberg, and Wagner (2011)
} 
Regulations have been passed to discourage the use of performance-related pay (via pan-European bonus caps) or at least mold performance-based compensation toward a longer-term focus (through mandatory deferral of compensation and clawback). However, as discussed above, due to shareholder pressure, these measures will not lead to an eradication of incentives to operate with high leverage. Shareholders who favor debt over increased equity will install managers with appropriate risk tolerances and managers will behave accordingly to, at least, save their jobs.

\section{B. Leverage Ratios as a Macroprudential Measure}

\section{i. The macroprudential toolkit}

When asset prices collapse, consumers default and the financial system amplifies the shock through fire sales and restriction of credit. Importantly, this view of macroprudential risk helps to explain the complex credit crunch dynamics, which may evolve between the traditional banking system and the shadow banking system, in the event of major asset (housing) price drops. Banks take deposits, make loans, and are subject to capital requirements. Non-bank intermediaries have higher risk tolerance levels and fund themselves through securitized assets, leaving them vulnerable to asset price falls and/or the drying up of liquidity in repo markets, a process, which, as explained above, blighted debt markets in the build up to and aftermath of the GFC.

It follows that macroprudential measures are designed with the principal aim of limiting the damage caused by fire sales at both retail and shadow banks, especially following a period of mortgage defaults. They aim to achieve this through three main channels: lowering lenders' losses; increasing banks' capital so that they may withstand losses from mortgage defaults; and preventing busts from quickly morphing into booms by limiting the effects of policies designed to support house prices following a bust from contributing to excessive price rises in the future.

Goodhart et al. (2013) identify five forms of macroprudential policy that may be imposed in order to limit the fallout from defaults in the housing market from causing serious damage to the banking system, which may eventually leak out into the wider economy. ${ }^{118}$ These are: (i) limits on loan-to-value ratios (LTV); (ii) higher capital requirements for banks; (iii) increased liquidity coverage ratios for banks; (iv) dynamic loan

${ }^{118}$ Goodhart et al. (2013) 
loss provisioning for banks; and (v) margin requirements on repurchase agreements used by shadow banks. ${ }^{119}$

Arguably, these tools may act as complements or hindrances to one another, depending upon the situation they are used to tackle and the extent to which financial stability safety concerns are balanced with the need for credit to flow to the wider economy. Thus, I examine below some of their key limitations.

\section{(a) Liquidity regulation}

In relation to liquidity requirements, forcing banks to hold a relatively high proportion of liquid assets will naturally reduce the supply of illiquid assets and mortgages will have to be securitized through issuance of longer-term bonds, which may not be feasible when markets are not very liquid. However, as with capital regulation, there are issues. Firstly, liquidity regulation is very procyclical. As with capital regulation, this is because if in bad times liquidity regulation becomes binding, banks will aim to securitize even more of their assets (being more liquid), which will add to any fire-sale trend in a downturn. Secondly, where a bank is forced by regulation to hold additional safe assets to satisfy liquidity ratios, the bank will "endogenously respond by recognizing that these assets allow them to raise more deposits."120

\section{(b) Dynamic provisioning}

This concept would require banks in good times to build up cash buffers against potential future loss, and may therefore be compared with the countercyclical buffer of Basel III. Depending upon the relative riskiness of the assets that banks must fund with cash, bank funding costs will increase to a corresponding degree. In the case of mortgages, banks will increase their interest rates in tandem with higher funding costs, which will restrict the availability of credit to some borrowers.

Of course, the task of refining regulations to counter instability generated by the relationship between housing markets and the banking system is highly complex. Severaloften competing — considerations must be balanced, especially governing the trade-off between financial stability concerns and the need to keep credit flowing to the real economy ${ }^{121}$ and the interests of many different constituents relative to the bank must be weighed before optimal regulation can be achieved. Moreover, the idea that restricting

\footnotetext{
${ }^{119}$ Goodhart et al. (2013)

${ }^{120}$ Kashyap, Tsomocos, and Vardoulakis (2014)

${ }^{121}$ Kashyap, Tsomocos, and Vardoulakis (2014)
} 
mortgage growth through a combination of RWA capital requirements, liquidity rules, and the imposition of larger haircuts on repo transactions is not straightforward because of the procyclical nature of these instruments and the impact of rising asset values on them as a “restraint” factor.

There is no concentration limit placed on portfolios by the Basel Accords. Whilst counterparty exposure limits are included in revisions of the Accords, in calculating default risk, the risk-weighting system does not take into account the fact that institutions may be exposed to an entire market—such as the housing market—in determining banks’ capital requirements. This so-called "portfolio invariance” is not reflective of the crucial importance of diversification on portfolio risk. On this basis, minimum capital requirements associated with any form of loan designed to mitigate credit risk rise in a linear way based on the asset type held, rather than based on the size of the exposure: on this basis, risk weights do "not penalize portfolio concentration." ${ }^{\text {,22 }}$ This is a very important concern when bank lending is concentrated in, for example, overheating housing markets, without breaching large exposure limits.

Arguably the most important limitation of the macroprudential measures examined above is that they are bound to have a limited (or even negligible) impact on price levels in the case of prime property markets open to foreign investment. Specifically, the traction that macroprudential measures such as LTV and loan-to-income (LTI) may have on property prices in a (prime) property market dominated by investors that is also open to significant flows of foreign capital is bound to be limited. This view is based on research about the composition of prime property market buyers in London and other parts of the UK, ${ }^{123}$ which have experienced substantial price increases, and also empirical evidence from Canada, where property buyers present the same characteristics of foreign origin and high net wealth. In the latter case, existing macroprudential measures have failed to show any appreciable traction on price levels in major cities that are an attraction for foreign buyers. ${ }^{124}$ Accordingly, under conditions of unrestricted flows of foreign investment in the overheated housing markets, LTV and LTI ratios are far from being a panacea. ${ }^{125}$

\footnotetext{
122 Blundell-Wignall and Atkinson (2010)

${ }^{123}$ A 2014 report for the British Property Federation found that the London property market was dominated by investor buyers (61 percent of all purchases in 2013) and that "buy to let investors" maintained a very strong presence (48 percent of all purchases) with a substantial portion of those investors being foreign residents. See British Property Federation (2014).

124 Schembri (2014)

125 See Avgouleas (2014)
} 


\section{ii. Leverage ratios as macroprudential stabilizers}

Leverage ratios have a clear macroprudential effect, albeit not as a perfect substitute for the monetary instrument. First, as mentioned earlier, contrary to intuition empirical evidence has shown that bank leverage rises during boom times and falls during downturns, producing bubbles and crashes. On the other hand, leverage restraints can restrict leverage building up not just at the level of financial institution but also across the financial system. Even if there are other credit intermediation channels in the economy, e.g., shadow banking channels, and financial institution leverage is not the only important factor in building up the credit cycle, the fact that individual financial institutions are not excessively leveraged would mean that the speed of deleveraging in the economy will become much slower in a downturn.

This will make all the difference, especially in a medium-severity downturn when corporations or households have little incentive to deleverage sharply, as it will keep the flows of credit relatively steady, avoiding a liquidity asphyxia. As a result leverage ratios can restrict the leverage cycle and thus contain the often-devastating impact of a leverage cycle crash. ${ }^{126}$ Secondly, it has an effect by placing a restraint on creditors under conditions of excessive liquidity since, even in the presence of a credible bail-in threats, excessive liquidity normally leads to a breakdown of creditor discipline; under such conditions they focus on their chase for yield in an artificially low interest rate environment. Finally, it is likely that the most important impact leverage ratios have, as opposed to RWAs, is a normative/moral one, in the form of a so-called "nudge.” Namely, they might in reality act as rules of thumb when it comes to prudent lending and reminders of the impact of excessive debt and thus alleviating what Borio and others have termed "entrenched instability,” where loose monetary policy precrisis is followed by an even looser one postcrisis. ${ }^{127}$

Arguably, it would be a folly to rely on bank leverage ratios to contain bubbles when so much business funding comes from shadow banks in the post-2013 period. At the same time, asset bubbles may really be, at least in part, the result of misaligned incentives among asset managers, ${ }^{128}$ who are queuing (herding) to take advantage of excessive liquidity and asset rises. In addition the Spanish experience with dynamic pre-provisioning, which like

\footnotetext{
${ }^{126}$ While they disagree with the Basel III leverage ratio, as regards the benefits of smoothing the "leverage cycle” Fostel and Yeanakoplos (2013) note: "Macroeconomic stability policy has concentrated almost entirely on regulating interest rates. But interest rates over the cycle in the Leverage Cycle example barely move. The leverage cycle suggests that it might be more effective to stabilize leverage than to stabilize interest rates."

127 "The risk of entrenching instability reflects a new form of time inconsistency, more insidious than the more familiar one in the context of inflation. Policies that are too timid in leaning against financial booms but that are then too aggressive and persistent in leaning against financial busts may end up leaving the authorities with no further ammunition over successive financial and business cycles.” Borio $(2014,16)$

128 Jones (2015)
} 
leverage ratios (and unlike countercyclical buffers) acts as a constant ex ante restraint on excessive lending, simply did not work in the face of very low interest rates. ${ }^{129}$

Spanish authorities were using the measure both to augment bank stability and to account for the fact that given interest rate uniformity within the eurozone, where the ECB sets one interest rate for the entire Union, the cost of money in Spain was grossly underpriced, given other fundamental conditions in the country, including competitiveness and the rate of inflation. ${ }^{130}$ Thus, pre-provisioning was used to put the brakes on bank lending as much as in order to make Spanish banks more resilient. Yet it failed to prevent the formation of gigantic asset bubbles.

For this and a variety of other reasons the recalibration of the monetary instrument may be essential for deflating or containing asset bubbles. As Claudio Borio argues not doing so will undermine the long-term credibility of central banks as monetary authorities ${ }^{131}$ and it would be a "folly” to just rely on "on the emerging fully fledged macroprudential frameworks to tackle the build-up of financial imbalances.”" ${ }^{\text {„32 }}$ Although the macroprudential framework does indeed strengthen the resilience of the financial system it cannot prevent booms and busts in the context of open markets.

Given the acknowledged importance of the credit supply conditions for housing bubbles, ${ }^{133}$ a potential solution to these issues would be to eliminate non-banks from the financial system. This would make the banking system much safer by reducing the supply of mortgages to the real economy and by lowering banks' aggregate exposure to the mortgage market. However, in terms of efficiency, this solution would be draconian. Mortgage prices would undoubtedly increase as their supply shrank and the costs of intermediating funds rose for banks. Further, banks would be deprived of an important risk-sharing mechanism for them to hedge and offset their liabilities.

\section{LEVERAGE RATIOS AND ECONOMIC GROWTH}

Proponents of high leverage contend that by reducing the costs of capital (by allowing banks to expand using debt rather than equity), leverage increases economic and allocative efficiency. The more credit is available to banks to extend, the more worthwhile projects are

\footnotetext{
${ }^{129}$ See Estrada and Saurina (2015); both authors of this impressive paper are with Spanish Central Bank.

${ }^{130}$ Estrada and Saurina (2015)

${ }^{131}$ See Borio (2014)

132 Borio (2014, 10); see also Vinals (2012).

${ }^{133}$ Muellbauer (2012)
} 
financed, and thus levels of capital investment in the economy increase. ${ }^{134}$ In addition, DeAngelo and Stulz (2014) stress the liquidity function of banks and argue for lower levels of equity capital. ${ }^{135}$ High leverage is optimal for banks in order to have a meaningful role in liquid-claim production (i.e., demandable deposits). Their model has a market premium for (socially valuable) safe/liquid debt in the form deposits, but no taxes or other traditional motives to lever up. Because only safe debt commands a liquidity premium, banks with risky assets use risk management to maximize their capacity to include such safe debt in the capital structure. DeAngelo and Stulz's model (2013, revised 2014) explains thus why banks have higher leverage than most industrial firms, and also that leverage limits for regulated banks impede their ability to compete with unregulated shadow banks. ${ }^{136}$

Another argument against restrictions on bank leverage is that such restrictions are bound to have an adverse impact on credit flows and consequently on economic growth. In many regions, and especially in the EU, banks are the largest single source of credit intermediation acting as vehicles for pooling public savings and transforming their maturities in order to serve long-term investment goals. Thus, leverage is fundamental to financial system development and economic growth, ${ }^{137}$ especially in Europe, where rapid bank deleveraging due to the new capital requirements is shown to harm small firms' access to external funding. ${ }^{138}$ A study published by the International Institute of Finance on the cumulative impact of Basel II capital requirements on economic growth suggests that the financial reforms under Basel III will lead to a 2.9 percent reduction in the level of real GDP by 2020, implying an annual GDP decline of 0.3 percent. ${ }^{139}$

Introduction of higher capital requirements in the banking sector has to balance several conflicting concerns, especially in relation to the potential adverse impact that leverage restrictions might have on the macroeconomic outlook. Besides risks inherent in modern banking could, arguably, be contained by other forms of capital requirements, liquidity standards, and the lender-of-last-resort facility.

Yet outside of the eurozone, which is an over-banked region and whose economy is disproportionately reliant on bank lending, the argument about the impact of leverage

\footnotetext{
${ }^{134}$ There is increasing evidence to suggest that there is a point at which excess private credit and financial development within an economy may start to hamper economic growth; see Arcand, Berkes, and Panizza (2012).

${ }^{135}$ DeAngelo and Stulz (2014)

${ }^{136}$ DeAngelo and Stulz (2014)

${ }^{137}$ The contribution of bank credit and financial system development to economic development is thoughtfully demonstrated in Levine (1997).

${ }^{138}$ European Investment Bank Report (2015)

${ }^{139}$ See Institute of International Finance (IIF) (2011)
} 
ratios on economic growth is not supported by the majority of recent studies. These show that leverage controls are an overall welfare-enhancing mechanism. ${ }^{140}$ To this effect, Miles, Yang, and Marcheggiano (2011) performed cost and benefit calculations on UK data and concluded that marginal benefits exceed marginal costs up to an equity capital level of 20 percent of RWA for UK banks. The social costs resulting from a 50 percent reduction of leverage are estimated to amount to 0.15 percent, or 3 percent if a discount rate of 5 percent is applied. ${ }^{141}$ Similarly, based on a survey of a large number of empirical studies of banking crises, the Basel Committee for Banking Supervision (BCBS) found that expected benefits of substantially higher capital requirements (raising the CET1 capital ratio by 100) amount to benefits of 5.21 percent assuming a discount factor of 5 percent. ${ }^{142}$ Even more recently, a Swiss study found that: "the increase of capital levels as foreseen by Basel III and the Swiss Too Big to Fail (TBTF) regulations will accordingly reduce the probability of systemic crisis by 3.6 percent and yield an expected permanent annual GDP benefit of 0.64 percent. Thus, social benefits exceed social costs by a factor of nearly 11."143 Even allowing for statistical errors this is a very convincing finding.

Miles et al. (2013) also engaged into a historical analysis of the perceived relationship between economic growth rates and levels of bank leverage and even more pertinently of the relationship between bank leverage levels and lending costs. In both cases they found correlation. ${ }^{144}$ Their findings are summarized as follows: ${ }^{145}$

\begin{abstract}
Between 1880 and 1960 bank leverage was_on average-about half the level of recent decades. Bank leverage has been on an upwards trend for 100 years; the average growth of the economy has shown no obvious trend .... Furthermore, it is not obvious that spreads on bank lending were significantly higher when banks had higher capital levels ... The absence of any clear link between the cost of bank loans and the leverage of banks is also evident in the US.
\end{abstract}

It is arguable that the beneficial impact of bank leverage might be more evident when lending markets are competitive. ${ }^{146}$ If this argument holds true, it means that a

\footnotetext{
${ }^{140}$ See Elliot (2009); Kashyap, Stein, and Hanson (2010); Miles, Yang, and Marcheggiano (2011)

${ }^{141}$ Miles, Yang, and Marcheggiano (2011)

142 BCBS (2010)

143 Junge and Kugler (2012, 4-6)

${ }^{144}$ Miles at al. (2013, 3-10)

145 Miles at al. (2013, 3-4)

${ }^{146}$ Christiano and Ikeda (2013), updated version of paper submitted to XVI Annual Conference of the Central Bank of Chile, "Macroeconomics and Financial Stability: Challenges for Monetary Policy," November 15-16, 2012, (arguing that leverage restrictions on banks generate a very substantial welfare gain in steady state). Available at:
} 
restrictive leverage ratio does not have a detrimental impact on growth when restrictions on competition are relaxed to allow new entrants into the market. This finding does not support the ring-fencing frameworks implemented in the UK and elsewhere. On the contrary if it holds true it calls into question the necessity of very strict restrictions on bank operations in the presence of comprehensive leverage caps.

Nonetheless, other studies show that even in less than perfectly competitive markets a leverage ratio seems to have beneficial impact on institutional and systemic stability without affecting growth. Another positive outcome may be that in economies with underdeveloped capital markets, especially risk capital markets such as venture capital and private equity, curbs on bank borrowing will allow these alternative forms of funding to thrive. This idea strongly underpins the EU Commission's proposals for a European Capital Markets Union. ${ }^{147}$

It is possible that the divergence between studies calculating the impact of leverage ratios (and other capital requirements) like the aforementioned IIF study is that the latter take into account historical data to quantify the financial stability benefits of new capital regulations. In countries like Switzerland and the US, where historical banking data is readily available, a study of the impact of higher capital requirements in these countries can ably measure, apart from costs, also the increased benefits of financial stability. On the other hand, once this is done requisite studies provide a strongly positive assessment of increased leverage ratios. The most recent empirical study, which has measured the impact from introduction of leverage ratios in Switzerland, has identified significant welfare gains instead of the feared losses. ${ }^{148}$

\section{NEW LEVERAGE RATIOS AND CAPITAL REGULATIONS}

\section{A. Is There an Optimal Bank Leverage Ratio?}

There are many good reasons why common equity is regarded as a superior form of bank capital. Among the most important is the fact that equity is perpetual and thus irredeemably anchored to the solvency of the bank for the duration of its life as a going concern. In addition, it ranks last in the event of insolvency, and is capable of being used to absorb bank losses. Also, as explained earlier, higher amounts of equity capital improve bank governance

http://faculty.wcas.northwestern.edu/ /christ/research/Ikeda/manuscript_submitted.pdf

${ }^{147}$ EU Commission (2015)

148 See Junge and Kugler (2012) 
in two ways. First, higher levels of equity control shareholders' preference to maximize risk and return by taking on more debt and curbs their willingness to lend to risky projects. Thus, equity funding of bank assets lowers bank governance costs.

One of the most important questions surrounding capital regulation is how much bank capital is enough? An important factor that makes this question exceedingly complex is that banks, unlike other corporations, are not just allowed to use as "own funds" broader equity capital, including capital reserves and retained profit, but also serious amounts of convertible debt. To a number of commentators bank capital should not just account for possible bank losses on some abstract weight-based ratios of asset riskiness, which is the fundamental rationale of Basel standards. It should also be a means to contain banking's externalities and thus it should target those parts of the system that generate the highest amounts of risk, either on their own or due to interconnectedness, accounting thus for the social cost (externalities) of bank failures.

How much equity capital banks require is not an easy question to answer. Prima facie, there is a tradeoff between business efficiency and bank safety. Yet the view that bank equity is more expensive than debt has strongly been disputed in a classic work by Admati et al. (2011). ${ }^{149}$ This view is corroborated by other studies (and by historical experience) which find that that due to the social costs involved in their operation, banks must hold much higher levels of capital than banks have held so far and higher than the Basel requirements. ${ }^{150}$ For example, Capie and Wood (2013) have found that British banks in the nineteenth century, during which there were a number of banking crises, responded to these crises by holding higher levels of capital. They show that banks adjusted their capital ratios according to the risks they assumed. ${ }^{151}$

Admati et al. (2011/revised 2013) suggest a Tier 1 equity ratio of 20-30 percent over unweighted assets would be socially optimal. On the other hand, Miles et al. (2011) argue for unweighted capital ratios of up to 20 percent. ${ }^{152}$ Their argument for higher (equity) capital requirements is twofold: (i) to reduce the probability of a public bailout and thus reduce the exposure of taxpayers; and (ii) to reduce incentives for managers to take excessive risks (and play games with risk). In fact, they make a clear distinction between costs to individual institutions (private costs) and overall economic (or social) costs. They estimate the long-run costs and benefits of having banks fund more of their assets with loss-

\footnotetext{
${ }^{149}$ Admati et al. (2011/rev. 2013).

${ }^{150}$ Miles, Yang, and Marcheggiano (2011)

${ }^{151}$ Capie and Wood (2013)

${ }^{152}$ Miles, Yang, and Marcheggiano (2011)
} 
absorbing equity capital. The benefits are related to the reduction of the chance of banking crises, which generate substantial economic costs. The offset to any such benefits comes in the form of potentially higher costs of bank intermediation (e.g., higher lending rates or lower savings rates). They find that the amount of equity capital that is likely to be desirable for banks to use is very much larger than banks have used in recent years and also higher than targets agreed upon under the Basel III framework.

\section{B. The New Leverage Regulations}

Unsurprisingly as the theoretical debate about an optimal ratio remains inconclusive this pluralism is also reflected in recent measures across key G-20 jurisdictions aiming at the adoption of binding leverage by their banks. The Basel III Accord requires banks to have a minimum of 6 percent Tier 1 capital (comprising 4.5 percent common equity and retained earnings). In an attempt to counter the effects of inadequate disclosure of banks' capital positions, the BCBS also requires, as a backstop, that banks operate with a minimum leverage ratio of 3 percent. ${ }^{153}$ Any bank with an unweighted leverage ratio of less than 3 percent will be deemed to be undercapitalized, although full implementation will not be achieved until 2018. The distinction between the two measures is that leverage ratios strip out the effects of risk-weighting models, and the ratios are calculated using the tightened definition of capital required under Basel III. ${ }^{154}$ The ratio is designed to place a limit on the capacity of banks to leverage their capital base, and to provide safeguards against possible RWA modeling error. ${ }^{155}$ Banks have been given until 2018 to comply fully with the leverage ratio.

Partly due to the extended timescale for Basel III implementation and partly due to the fact that the Basel III leverage ratio of 3 percent of non-weighted assets is arguably very low, certain jurisdictions have drawn up their own plans for imposing a leverage ratio. Many have chosen to go substantially higher than the Basel III 3 percent ratio.

The Federal Reserve is required to establish the enhanced risk-based and leverage capital requirements for “covered companies,” i.e., bank holding companies with total consolidated assets of at least $\$ 50$ billion and non-bank financial companies that the Financial Stability Oversight Council has designated for supervision by the

\footnotetext{
153 BCBS (2011, 61); the leverage ratio is defined as the quarterly average total assets less deductions that include goodwill, investments deducted from Tier 1 capital, and deferred taxes; see D’Hulster (2009, 2).

154 BCBS $(2011,12)$

155 As the BCBS $(2011,2)$ has noted, "the [GFC] demonstrated that credit losses and writedowns come out of retained earnings, which is part of banks’ tangible common equity base.”
} 
Federal Reserve Board. ${ }^{156}$ Banks and other financial organizations are required to report to the market and regulators on their leverage ratio at regular intervals under the Prompt Corrective Action (PCA) regulations. Given the aforementioned failure of the previous American leverage ratio to warn of impending disaster, mostly because off-balance-sheet exposures went unnoticed, the Dodd-Frank Act has adopted a more sophisticated approach to bank leverage measures. The leverage ratio itself for all banking organizations is set at 4 percent, ${ }^{157}$ although certain large banking organizations are subject to a lower leverage ratio if they utilize the advanced IRB approach to RWAs, which require them to have a minimum total leverage exposure of 3 percent. ${ }^{158}$ However, a further supplementary rule has been introduced to cover the largest and most interconnected bank holding companies (BHCs), defined as those with more than $\$ 700$ billion in consolidated total assets, or $\$ 10$ trillion in assets under custody (covered BHCs). These banks would be required to maintain a Tier 1 capital leverage buffer of at least 2 percent above the minimum supplementary leverage ratio requirement of 3 percent (for banks which use the advanced IRB approach), for a total of 5 percent. Insured subsidiaries of BHCs ("Insured Depository Institutions”) must maintain at least a 6 percent supplementary leverage ratio to be considered "well capitalized" under the agency’s PCA framework. ${ }^{159}$ Failure to exceed the 5 percent ratio would subject covered BHCs to restrictions on discretionary bonus payments and capital distributions. This rule would currently apply to the eight largest and most interconnected US banks, although it will not be implemented in its entirety until January 2018. Furthermore, there are additional requirements for leverage restrictions in times of crisis. ${ }^{160}$

In the EU, regulators use the Basel III Accord as a template for action. However, whilst the rules of the instruments included in the framework of the Capital Requirements Directive IV (CRD IV) ${ }^{161}$ require that institutions calculate and report on their leverage

\footnotetext{
${ }^{156}$ See Dodd-Frank Wall Street Reform and Consumer Protection Act, Pub, L. No. 111/203 (July 21, 2010) Pub. L. No. 124 Stat. 1376 § 165.

${ }^{157}$ See Regulatory Capital Rules: Regulatory Capital, Enhanced Supplementary Leverage Ratio Standards for Certain Bank Holding Companies and Their Subsidiary Insured Depository Institutions, 79 Fed. Reg. 24,528 (Final Rule, May 1, 2014) (12 C.F.R pts. 6, 208, 217, 324).at 62,030.

${ }^{158}$ Ibid. at 62,143

159 Ibid.

${ }^{160}$ Dodd-Frank places a limit of 15:1 leverage for an institution with \$50 billion of assets or more that poses a "grave threat to the financial stability of the US when such a limit would mitigate the threat." Dodd-Frank Act, $\S 165(j)(1)$. This limitation applies in very narrow circumstances, and is designed as a remedial, rather than a preventative measure, triggered to contain a risk once it has been identified rather than to prevent risk from materializing. See id.

${ }^{161}$ See Directive 2013/36/EU of the European Parliament and of the Council June 26, 2013 on access to the activity of credit institutions and the prudential supervision of credit institutions and investment firms,
} 
ratios, CRD IV does not propose a minimum leverage ratio. The European Commission has charged the European Banking Authority with monitoring the implementation of Basel III and reporting on whether the 3 percent minimum leverage ratio is appropriate for European financial institutions. If they can agree on a definition for the leverage ratio, a standardized ratio should be implemented across the EU by January 2018. ${ }^{162}$ Institutions must, however, report their simplified leverage ratios to regulators starting January 1, 2015.

The Canadian "assets to capital multiple” is a rather comprehensive leverage ratio, because it also measures economic leverage (to some extent). It is applied at the level of the consolidated banking group by dividing an institution's total adjusted consolidated assetsincluding some off-balance-sheet items—-by its consolidated (Tier 1 and 2) capital. Under this requirement total adjusted assets should be no greater than 20 times capital, although a lower multiple can be imposed for individual banks by the Canadian supervisory agency, the Office of the Superintendent of Financial Institutions (OSFI). This is more conservative than the previous US incarnation of the leverage ratio-and the inclusion of off-balance-sheet items strengthens the ratio even more. Indeed, the stringency of Canada's leverage ratio has been cited as one factor-along with sound supervision and regulation, good cooperation between regulatory agencies, strict capital requirements, and conservative lending practices-contributing to the strong performance of its financial sector during the financial crisis. $^{163}$

In 2008 the Swiss regulator FINMA (Financial Market Supervisory Authority), in strengthening capital adequacy requirements, introduced a minimum leverage ratio under Pillar 2 of Basel II (supervisory review) solely for the country’s two biggest banks, Credit Suisse and UBS. ${ }^{164}$ The Swiss leverage ratio is based upon the Basel III definition of Tier 1 capital as a proportion of total adjusted assets and is set at a minimum of 3 percent at the consolidated level and 4 percent at the individual bank level. ${ }^{165}$ To calculate the leverage ratio, the balance sheet under International Financial Reporting Standards (IFRS) is adjusted for a number of factors. Some adjustments provided are very common, such as exclusion of the replacement values of derivatives to reduce the effects of the strict netting rules under

amending Directive 2002/87/EC and repealing Directives 2006/48/EC and 2006/49/EC, O.J. (L176/338) (June 27, 2013) (the EU Capital Requirements Directive).

162 See, in general, “Supervisory Review,” European Banking Authority, November 15, 2014. Available at: http://www.eba.europa.eu/supervisory-convergence/supervisory-disclosure/supervisory-review

${ }^{163}$ Office of the Superintendent of Financial Institutions Canada (2007); see also Crawford, Graham, and Bordeleau (2009) on evaluating the impact of Canadian leverage regulations.

${ }^{164}$ Reports indicate that both banks are on course to meet the new leverage requirements; see Swiss National Bank Financial Stability Report 5 (2013). Available at: http://www.snb.ch/en/mmr/reference/stabrep_2013/source/stabrep_2013.en.pdf ${ }^{165}$ See FINMA (2011) 
IFRS. On the other hand, the deduction of the entire domestic loan book ${ }^{166}$ indicated that the Swiss authorities wanted to ensure that the leverage ratio would not hamper the expansion of the domestic credit market in the middle of a recession. The restriction was removed in 2013. ${ }^{167}$ In fact, the Swiss government has considered raising the leverage ratio up to 10 percent-naturally attracting the wrath of the Swiss banking industry ${ }^{168}$ — because it regards the current 4 percent ratio inadequate.

The UK’s Bank of England has recently announced a new leverage ratio, which will be binding on all banks regulated by the Prudential Regulation Authority (PRA) by $2018 .{ }^{169}$ This followed on from work done by the Independent Commission on Banking (chaired by Sir John Vickers) ${ }^{170}$ which recommended that large UK ring-fenced banks ought to be subject to a supplementary leverage ratio of approximately 4 percent. ${ }^{171}$

Accordingly, the PRA is to be empowered to set a minimum leverage ratio of 3 percent for all UK financial institutions; a supplementary leverage ratio for systemicallyimportant financial institutions (a 35 percent buffer, calibrated in proportion to the Basel III risk-weighted framework), thereby preserving the relationship between the 3 percent minimum leverage requirement and the 8.5 percent Tier 1 risk-weighted capital requirement (the latter including both the minimum and the capital conservation buffer) ${ }^{172}$; and a countercyclical leverage ratio buffer (CCLB), again, calculated in proportion to the Basel III countercyclical buffer (CCB). The Bank of England argues that mimicking the Basel III riskweighting system “achieve[s] complementarity between the leverage and risk-weighted framework." ${ }^{173}$ Under these proposals, large systemically important UK banks will have to comply with a leverage ratio of 4.05 percent. This may also be increased at the discretion of the PRA to require higher levels of capital based on the activation of the CCB. The Bank of England expects that it would set the CCLB rate at 35 percent of the CCB rate. This would imply a CCLB rate of between 0.35 percent and 0.875 percent, based on the Basel global systemically important banks (G-SIB) framework, which applies overall buffer rates of

\footnotetext{
${ }^{166}$ See EBK und Grossbanken einigen sich auf höhere Eigenmittelziele und die Einführung einer Leverage Ratio, Medienmitteilung der Eidgenössischen Bankenkommission’ (Dec. 2008). Available at: http://www.finma.ch/archiv/ebk/d/publik/medienmit/20081204/mm-em-leverageratio-20081204-d.pdf

${ }^{167}$ On the vagaries and continuous development of the Swiss leverage ratio, see Kellermann and Schlag (2013).

168 See Miles and Ireland (2013).

${ }^{169}$ See Bank of England (2014).

${ }^{170}$ See Vickers (2011).

${ }^{171}$ This proposal won support from several leading UK central bankers, including Sir Mervyn King, former Governor of the Bank of England, and Andrew Haldane, Executive Director for Financial Stability at the Bank of England. Indeed, Haldane has argued for a leverage ratio of between 4 and 7 percent; see Haldane and Madouros (2012).

172 Bank of England $(2014,6)$

${ }^{173}$ Bank of England (2014)
} 
between 1 percent and 2.5 percent. ${ }^{174}$ On this basis, systemically important UK banks may have to comply with a minimum total leverage ratio of 4.95 percent, although this would only occur if the maximum CCB had been activated under the Basel III system. It is perhaps noteworthy that, notwithstanding these increases in the leverage requirement, there has been widespread relief amongst the UK banking industry that tougher regulations were not imposed. $^{175}$

\section{CONCLUDING REMARKS}

Unweighted leverage ratios raise four key concerns: (i) the fear of adverse selection; (ii) the scope of the ratio; (iii) cycle insensitivity; and (d) impact on economic growth and, to some extent, money circulation. Some of these questions have found convincing answers. The new generation of leverage ratios implemented in the US, Canada, the UK, and Switzerland are catching off-balance-sheet exposures, resolving issues of scope. There is lots of anecdotal but no hard evidence to point to the fact that higher leverage ratios increase the cost of lending. But as regards a possible adverse impact on economic growth, this is probably negligible in countries with developed capital markets like the UK or the US. Nonetheless, the picture in the eurozone may be sharply different.

In the case of the new generation of ring-fenced/separated commercial banks, the adverse selection risk refers less to choosing risky loans and more to possible overconcentrating on housing market loans and attendant exposure to the housing market cycle. Finally, the Bank of England's ingenuous way of calculating and adjusting leverage on the basis of the movement of the economic cycle means that any concerns about unduly restricting lending during a downturn are largely ameliorated.

This paper has explained why properly calibrated leverage ratios may prevent wasteful use of capital and make financial institutions more resilient. They control asset substitution and risk shifting. Essentially, banks have to increase the size of their capital cushions, no matter the risk weighting of the relevant exposures and in proportion to the net increase in value of the bank assets. An unweighted leverage ratio is simple to apply and monitor and eliminates regulatory arbitrage, namely the bank's ability to engage in RWO restoring confidence in bank capital data that was severely undermined by the dual advent of risk-weighted capital requirements and financial innovation.

\footnotetext{
${ }^{174}$ Bank of England $(2014,17)$

${ }^{175}$ Indicatively, see Fleming (2014).
} 
For the same reason, leverage ratios may remedy weaknesses of creditor monitoring of banks in the face of complexity and opacity of bank balance sheets. As explained earlier banks' access to significant funding sources allows them to engage in rapid and frequent asset substitution and banks may use this capacity to shift assets in order to grow their balance sheets beyond optimal levels, prejudicing creditor interests.

The foregone analysis has provided an extensive explanation of why a wellcalibrated leverage ratio can prove an effective measure for controlling rent seeking and for smoothing up the leverage cycle to improve bank governance; especially the governance benefits, partly hidden as they are, can prove very tangible. All bankers want to advance their careers or, at the very least, keep their jobs. When competitors pile up leverage to maximize RoE, even benign managers will follow the short-termist path and herd, notwithstanding that their compensation may be aligned to the bank’s long-term performance. The natural consequence of excessive leverage is ever more risk-taking and rent seeking. Leverage, in combination with the general opacity of bank balance sheets and asset substitution, creates serious information asymmetries between bank management and their monitors, which merely adds to the ineffectiveness of market discipline in the banking sector. $^{176}$

Finally, leverage ratios can prove an effective macroprudential measure aimed at stabilizing the financial system as a whole. They cannot, however, replace monetary policy, when they are used in a backdrop of excessive liquidity, due to very loose monetary policy or the reinvestment of trade surpluses, in the case of attractive (and open) host markets. Therefore, the financial stability dilemmas surrounding loose monetary policies will remain an intractable economic policy and intellectual problem, even in the face of a new spate of well-thought out and well-calibrated leverage ratios like those being implemented in key financial centers. But by making the banking sector more resilient, the new generation of bank leverage ratios will at the very least substantially reduce endogenous risks and financial panics augmenting the stability of the financial system as a whole.

\footnotetext{
${ }^{176}$ Hellwig (2009); Avgouleas and Cullen (2015)
} 


\section{References}

Acharya, V.V., H. Mehran, and A. Thakor. 2010. "Caught between Scylla and Charybdis? Regulating Bank Leverage When There Is Rent Seeking and Risk Shifting.” Federal Reserve Bank of New York Staff Report No. 469.

Acharya, V.V., P. Schnabl, and G. Suarez. 2010. "Securitization Without Risk Transfer.” NBER Working Paper 15730, February.

Acharya, V.V., and M. Richardson. 2009. "Causes of the Financial Crisis.” Critical Review 21(2-3): 195-210.

Acharya, V.V., and P. Schnabl. 2009. "How Banks Played the Leverage 'Game.”' in Viral V. Acharya and Matthew Richardson (eds.), Restoring Financial Stability: How to Repair a Failed System. Hoboken, NJ: Wiley.

Admati, A., P.M. DeMarzo, M.F. Hellwig, and P.C. Pfleiderer. 2014. “The Leverage Ratchet Effect.” Rock Center for Corporate Governance at Stanford University Working Paper No. 146, May.

Admati A., P.M. DeMarzo, M.F. Hellwig, and P.C. Pfleiderer. 2012. "Debt Overhang and Capital Regulation.” (Rock Center for Corporate Governance at Stanford University Working Paper Series No. 114, Preprints of the Max Planck Institute for Research on Collective Goods No. 2012/5). Stanford, Bonn 2012.

Admati, A.R., P.M. DeMarzo, M.F. Hellwig, and P. Pfleiderer. 2011 [revised 2013]. "Fallacies, Irrelevant Facts, and Myths in the Discussion of Capital Regulation: Why Bank Equity is Not Expensive.” First published as Rock Center for Corporate Governance at Stanford University Working Paper No. 86, March 2011. Revised mimeo 2013, October. Available at https://www.gsb.stanford.edu/sites/default/files/research/documents/Fallacies\%20No v\%201.pdf

Adrian, T., and H.S. Shin. 2010. “Liquidity and Leverage.” Journal of Financial Intermediation 19.

Albertazzi, U., and L. Gambacorta. 2009. "Bank profitability and the business cycle.” Journal of Financial Stability 5: 393-409.

Alcidi, C., and D. Gros. 2012. "The Spanish hangover.” Vox.eu, April 15. Available at: http://www.voxeu.org/article/whats-wrong-spain

Arcand, J.-L., E. Berkes, and U. Panizza. 2012. “Too Much Finance?” IMF Working Paper No. $12 / 161$.

Avgouleas, E. 2015. “Fractional Reserve Banks.” in D. Arner, E. Avgouleas, and R. Buckley (eds.) Reconceptualising Global Finance and its Regulation. Cambridge: Cambridge University Press. 
Avgouleas, E. 2014. "Governance Costs of Bank Leverage and the Boom in UK Housing Markets.” Paper presented at National Institute for Economic and Social Research/Economic and Social Research Council/Centre for Macroeconomics Third Annual Finance conference "The Future of Housing Finance.” September 12. Available at: http://www.centreformacroeconomics.ac.uk/pdf/Event-201409NIESRHousing-

Avgouleas, E. 2011. "The Vexed Issue of Short Sales Regulation and the Global Financial Crisis.” in K. Alexander and N. Maloney (eds.), Law Reform and Financial Markets. Cheltenham: Edward Elgar Publishing.

Avgouleas, E. 2009. "The Global Financial Crisis, Behavioural Finance and Financial Regulation: In Search of a New Orthodoxy.” Journal of Corporate Law Studies 9: 23-59.

Avgouleas, E., and J. Cullen. 2015. “Excessive Leverage and Bankers’ Pay: Governance and Financial Stability Costs of a Symbiotic Relationship.” Columbia Journal of European Law 21(2).

Avgouleas, E., and J. Cullen. 2014. "Market Discipline and Corporate Governance in the EU Banking Sector: Intellectual Fallacies, Cognitive Boundaries, and Groupthink.” Journal of Law and Society 41: 28-50.

Avgouleas, E., and C.A.E. Goodhart. 2015. “Critical Reflections on Bank Bail-ins.” Journal of Financial Regulation 1: 1-27.

Bailey, A. 2013. “Bank of England 2012 Financial Stability Report.” Testimony before the Treasury Select Committee, UK House of Commons, January 15.

Bank of England. 2014. “The Financial Policy Committee’s Review of the Leverage Ratio.” October.

Bank of England. 2013. "News Release-Prudential Regulation Authority (PRA) completes capital shortfall exercise with major UK banks and building societies.” Available at: <http://www.bankofengland.co.uk/publications/Pages/news/2013/081.aspx>.

Barclays Equity Research. 2012a. “Bye Bye Basel? Making Basel More Relevant.” May 23.

Barclay’s Equity Research. 2012b. “The Dog That Dug: (Yet) More Digging Into RWAs...” September 21.

Basel Committee for Banking Supervision (BCBS). 2013. "Regulatory Consistency Assessment Programme-Analysis of Risk-Weighted Assets for Market Risk.” January.

BCBS (Basel III). 2011. "A global regulatory framework for more resilient banks and banking systems.” (December 2010; revised June 2011). 
BCBS. 2010. "An assessment of the long-term economic impact of stronger capital and liquidity requirements.” August.

Bebchuk, L.A., A. Cohen, and H. Spamann. 2010. “The Wages of Failure: Executive Compensation at Bear Stearns and Lehman 2000-2008.” Harvard Law School Discussion Paper No. 657.

Blair, M.M. 2013. “Leverage and Private Sector Money Creation.” Seattle University Law Review 36: 417, 438.

Blundell-Wignall, A., and P.E. Atkinson. 2012. "Deleveraging, Traditional versus Capital Markets Banking and the Urgent Need to Separate and Recapitalise G-SIFI Banks.” OECD Journal of Financial Market Trends 2012/1.

Blundell-Wignall, A., and P.E. Atkinson. 2011. "Global SIFIs, Derivatives and Financial Stability.” OECD Journal of Financial Market Trends 2011/1: 19.

Blundell-Wignall, A., and P.E. Atkinson. 2010. "Thinking Beyond Basel III: Necessary Solutions for Capital and Liquidity.” OECD Journal of Financial Market Trends 2010/1.

Blundell-Wignall, A., and C. Roulet. 2013. "Business models of banks, leverage and the distance-to-default.” OECD Journal of Financial Market Trends 2012/2.

Boot, Arnoud W.A. 2001. "Banking at the Cross Roads: How to Deal with Marketability and Complexity.” Amsterdam Center for Law and Economics Working Paper No. 201107, April.

Boot, Arnoud W.A., and A.V. Thakor. 2000. "Can Relationship Banking Survive Competition?” Journal of Finance 55(2): 679-713.

Borio, C. 2014. "Monetary policy and financial stability: what role in prevention and recovery?” BIS Working Paper No. 440, January.

Borio, C., and P. Lowe. 2002. "Asset prices, financial and monetary stability: exploring the nexus.” BIS Working Paper No. 114, July.

Bradley, M., C. Wambeke, and D. Whidbee. 1991. "Risk weights, risk-based capital, and deposit insurance.” Journal of Banking and Finance 15: 875-93.

British Property Federation (BPF). 2014. “Who Buys New Homes in London and Why?” Report, February.

Brunnermeier, M.K. 2009. “Deciphering the Liquidity and Credit Crunch 2007-2008.” Journal of Economic Perspectives 23: 77, 80.

Brunnermeier, M.K., and L. Pedersen. 2009. "Market Liquidity and Funding Liquidity.” Review of Financial Studies 22: 2201-38. 
Caballero, R.J., and A. Krishnamurthy. 2009. “Global Imbalances and Financial Fragility.” NBER Working Paper No. 14688.

Calomiris, C., and C. Kahn. 1991. "The Role of Demandable Debt in Structuring Optimal Banking Arrangements.” American Economic Review 81: 497.

Capie, F., and G. Wood. 2013. "Do we need regulation of bank capital? Some evidence from the UK.” Institute of Economic Affairs Current Controversies, No. 40, March 27.

Available at: http://www.iea.org.uk/sites/default/files/publications/files/Do\%20we\%20need\%20re gulation\%20of\%20bank\%20capital.pdf

Directive 2013/36/EU of the European Parliament and of the Council June 26, 2013 on access to the activity of credit institutions and the prudential supervision of credit institutions and investment firms, amending Directive 2002/87/EC and repealing Directives 2006/48/EC and 2006/49/EC, O.J. (L176/338) (27 June 2013) (the EU Capital Requirements Directive) (CRD IV).

Chen, C.R., T.L. Steiner, and A.M. Whyte. 2006. "Does Stock-Option-Based Compensation Induce Risk-Taking? An Analysis of the Banking Industry.” Journal of Banking and Finance 30: 915.

Chesney, M., J. Stromberg, and A.F. Wagner. 2011. "Risk-taking Incentives, Governance, and Losses in the Financial Crisis.” University of Zurich Swiss Financial Institute Working Paper No. 10-18.

Christiano, L., and D. Ikeda. 2013. "Leverage Restrictions in a Business Cycle Model.” Updated version of paper submitted to XVI Annual Conference of the Central Bank of Chile, "Macroeconomics and Financial Stability: Challenges for Monetary Policy," November 15-16, 2012. Available at:

http://faculty.wcas.northwestern.edu/ lchrist/research/Ikeda/manuscript_submitted.p $\mathrm{df}$

Crawford, A., C. Graham, and É. Bordeleau. 2009. "Regulatory Constraints on Leverage: The Canadian Experience.” Bank of Canada Financial System Review: Reports 45.

D’Hulster, Katia. 2009. “The Leverage Ratio: A New Binding Limit on Banks.” World Bank Group, Financial Sector and Private Sector Vice-Presidency, Paper 1. Available at: http://www.worldbank.org/financialcrisis/pdf/levrage-ratio-web.pdf.

DeAngelo, H., and R.M. Stulz. 2014. "Liquid-Claim Production, Risk Management, and Bank Capital Structure: Why High Leverage is Optimal for Banks.” Fisher College of Business Working Paper No. 2013-03-08, October.

Delis, M.D., K. Tran, and E. Tsionas. 2011. "Quantifying and explaining parameter heterogeneity in e capital regulation-bank risk nexus.” Journal of Financial Stability 8: 57-68. 
Dellepiane, S., N. Hardiman, and J. Las Heras. 2013. "Building on easy money: the political economy of housing bubbles in Ireland and Spain.” UCD, Geary Institute WP2013/18, October. Available at: http://www.ucd.ie/geary/static/publications/workingpapers/gearywp201318.pdf

Diamond, D.W., and R.G. Rajan. 2001. "Liquidity Risk, Liquidity Creation and Financial Fragility: A Theory of Banking.” Journal of Political Economy 109: 287-327.

Dodd-Frank Wall Street Reform and Consumer Protection Act of 2010, Pub.L. 111-203, 124 Stat. 1376-2223

Elliot, D.J. 2010. “A Primer on Bank Capital.” Mimeo. Brooking Institution, January. Available at: http://www.brookings.edu/ /media/research/files/papers/2010/1/29capital-elliott/0129_capital_primer_elliott.pd

Elliot, D.J. 2009. “Quantifying the Effects on Lending of Increased Capital Requirements.” The Brookings Institution Working Paper, September 21.

Estrada, A., and J. Saurina. 2015. "Spanish Boom and Bust: Some lessons for macroprudential policy.” Mimeo Bank of Spain. Presented at "Banking and regulation: the next frontier," a joint workshop by the Research Task Force of the Basel Committee on Banking Supervision, the Centre for Economic Policy Research, and the Journal of Financial Intermediation, Bank for International Settlements, Basel, Switzerland, January 22-23. Available at: http://www.bis.org/bcbs/events/bartnf/programme.pdf.

EU Commission. 2015. “Building a Capital Markets Union.” Green Paper, Brussels, 18.2.2015 COM, 63 final.

European Banking Federation. 2010. "Bank Leverage and Its Economic Implications.”

European Investment Bank Report. 2015. “Restoring EU competitiveness.” February: vii, 22-23.

Financial Services Authority. 2009. "The Turner Review: A Regulatory Response to the Global Financial Crisis.” Available at: http://www.fsa.gov.uk/pubs/other/turner_review.pdf.20.

FINMA. 2011. “Addressing Too Big To Fail: The Swiss Sifi Policy (2011).” Available at: http://www.finma.ch/e/finma/publikationen/Documents/be-swiss-SIFI-policy-june2011-summary-20110624-e.pdf.

Fisher, I. 1933 “The Debt Deflation Theory of Great Depressions.” Econometrica 1.

FitzGerald, J. 2009. "Blowing Bubbles_and Bursting Them: The Case of Ireland and Spain.” Euroframe conference paper, June. Available at: http://www.euroframe.org/files/user_upload/euroframe/docs/2009/EUROF09_FitzGe rald.pdf 
Fleming, S. 2014. “Banks Breathe Sigh of Relief Over UK Leverage Ratio.” Financial Times, October 31.

Fostel, A., and J. Geanakoplos. 2013. “Reviewing the Leverage Cycle.” Cowles Foundation Discussion Paper No. 1918, September.

Financial Services Authority (FSA). 2009. "Reforming remuneration practices in financial services: Feedback on CP09/10 and final rules.” PS 09/15, August, 4.24-4.27.

Gale, D. 2010. “Capital Regulation and Risk-Sharing.” International Journal of Central Banking 6(4): 187-204.

Geanakoplos, John. 2010a. "Solving the Present Crisis and Managing the Leverage Cycle.” Federal Reserve Bank of New York Economic Policy Review.

Geanakoplos, John. 2010b. “The Leverage Cycle.” in D. Acemoglu, K. Rogoff, and M. Woodford (eds.), NBER Macroeconomics Annual 2009, Vol. 24. Chicago: University of Chicago Press.

Gennaioli, N., A. Shleifer, and R.W. Vishny. 2010. "Neglected Risks, Financial Innovation, and Financial Fragility.” FEEM Working Paper No.114.2010, October.

Goodhart, C.A.E. 2011. “Global MacroEconomic and Financial Supervision: Where Next?” NBER Working Paper No. 17682, December.

Goodhart, C.A.E., A.K. Kashyap, D.P. Tsomocos, A.P. Vardoulakis. 2013. “An Integrated Framework for Analyzing Multiple Financial Regulations.” International Journal of Central Banking 9: 109-43.

Gorton, G., and A. Metrick. 2012. “Securitized banking and the run on repo.” Journal of Financial Economics 104: 425.

Graham, J.R., C.R. Harvey, and S. Rajgopal. 2015. "The Economic Implications of Corporate Financial Reporting.” Journal of Accounting and Economics 40: 3.

Haldane, A.G. 2011. "Control rights (and wrongs).” Speech given at the Wincott Annual Memorial Lecture, October 24. Available at: http://www.bankofengland.co.uk/publications/Documents/speeches/2011/speech525. pdf.

Haldane, A.G., and V. Madouros. 2012. “The Dog and the Frisbee.” Paper given at the Federal Reserve Bank of Kansas City’s 36th economic policy symposium, "The Changing Policy Landscape,” Jackson Hole, WY, August 31.

Hanson, S.G., A.K. Kashyap, and J.C. Stein. 2011. “A Macroprudential Approach to Financial Regulation.” Journal of Economic Perspectives 25: 3-28. 
Hellwig, M.F. 2014. "Financial Stability, Monetary Policy, Banking Supervision, and Central Banking.” Reprints of the Max Planck Institute for Research on Collective Goods, Bonn 9/2014, July. Available at: http://www.coll.mpg.de/pdf_dat/2014_09online.pdf

Hellwig, M.F. 2009. “A Reconsideration of the Jensen-Meckling Model of Outside Finance.” Journal of Financial Intermediation 18: 495.

Hunt, J.P. 2009. “Credit Rating Agencies and the 'Worldwide Credit Crisis': The Limits of Reputation, the Insufficiency of Reform, and a Proposal for Improvement.” Columbia Business Law Review 1: 1.

International Monetary Fund (IMF). 2008. "Global Financial Stability Report: Containing Systemic Risks and Restoring Financial Soundness.” April.

Ingves, S. 2013. “From ideas to implementation.” Remarks at the 8th High Level Meeting organized by the Basel Committee on Banking Supervision and the Financial Stability Institute and hosted by the South African Reserve Bank, Cape Town, January 24. Available at: <http://www.bis.org/review/r130124a.pdf>.

Institute of International Finance (IIF). 2011. “The Cumulative Impact on the Global Economy of Changes in the Financial Regulatory Framework.” Available at: www.iif.com

Jeitschko, T.D., and S.D. Jeung. 2005. "Incentives for risk-taking in banking-A unified approach.” Journal of Banking and Finance 29: 759-77.

Jones, B. 2015. “Asset Bubbles: Re-thinking Policy for the Age of Asset Management.” IMF Working Paper, Monetary and Capital Markets Department, WP/15/27, February. Available at https://www.imf.org/external/pubs/ft/wp/2015/wp1527.pdf

Junge, G., and P. Kugler. 2012.”Quantifying the impact of higher capital requirements on the Swiss economy.” Mimeo, May 17. Available at: http://wwz.unibas.ch/fileadmin/wwz/redaktion/makro/Papers/G_Junge_P_Kugler_Jul y_02_2012_V3_fina.pdf

Kahane, Y. 1977. “Capital adequacy and the regulation of financial intermediaries.” Journal of Banking and Finance 1: 207-18.

Kalemli-Ozcan, S., B. Sorensen, and S. Yesiltas. 2012. "Leverage across firms, banks and countries.” Journal of International Economics 88: 284-98.

Kashyap, A.K., D.P. Tsomocos, and A.P. Vardoulakis. 2014. "Principles for macroprudential regulation, Macroprudential policies: implementation and interactions.” Banque de France Financial Stability Review 18: 173-82.

Kashyap, K., J. Stein, and S. Hanson. 2010. "An Analysis of the Impact of 'Substantially Heightened' Capital Requirements on Large Financial Institutions.” mimeo, 2010, available at http://www.hbs.edu/faculty/Pages/item.aspx?num=41199 
Kay, J. 2010. "Should we have 'narrow banking'?” in The Future of Finance, The LSE Report.

Keeley, M., and F. Furlong. 1990. "A reexamination of the mean-variance analysis of bank capital regulation.” Journal of Banking and Finance 14: 69-84.

Kellermann, K., and C.-H. Schlag. 2013. “Occupy Risk Weighting: How the Minimum Leverage Ratio Dominates Capital Requirements-A Swiss Example.” Journal of Financial Regulation and Compliance 21: 353.

Keynes, J.M. 1936. The General Theory of Employment, Interest, and Money. London: Palgrave MacMillan.

Kim, D., and A. Santomero. 1988. "Risk in banking and capital regulation.” Journal of Finance 43: 1219-33.

Kindleberger, C.P., and R.Z. Aliber. 2005. Manias, Panics and Crashes: A History of Financial Crises, 5th edition. Basingstoke: Palgrave MacMillan.

Kiyotaki, N., and J. Moore. 1997. “Credit Cycles.” Journal of Political Economy 105(2): 211-48.

Koehn, M., and A. Santomero. 1980. "Regulation of bank capital and portfolio risk.” Journal of Finance 35: 1235-44.

Kotlikoff, L. 2012. “Vickers is not enough to stop another Libor scandal.” Financial Times, July 9.

Laeven, L., and R. Levine. 2009. "Bank governance, regulation and risk taking.” Journal of Financial Economics 93: 259.

Levine, R. 2004. “The Corporate Governance of Banks: A Concise Discussion of Concepts and Evidence.” World Bank Policy Research Paper 3404.

Levine, R. 1997. "Financial Development and Economic Growth: Views and Agenda.” Journal of Economic Literature 35: 688.

Masters, B. 2013. “The Leverage Story Banks Want to Hide.” Financial Times, Inside Business, April 8. Available at: http://www.ft.com/cms/s/0/3c660d16-a02e-11e288b6-00144feabdc0.html\#axzz2jKIBdtl9

Merton, R.C. 1977. “An Analytic Derivation of the Cost of Deposit Insurance and Loan Guarantees: An Application of Modern Option Pricing Theory.” Journal of Banking and Finance 1: 3-11.

Miles, D., J. Yang, and G. Marcheggiano. 2011. “Optimal Bank Capital.” CEPR Discussion paper 8333, April.. 
Miles, T., and L. Ireland. 2013. "UBS Chief Says Swiss Plan to Raise Leverage Ratio is Unrealistic.” Reuters, December 15. Available at: http://www.reuters.com/article/2013/12/15/us-swiss-banksidUSBRE9BE03X20131215.

Minsky, H.P. 1992. “The Financial Instability Hypothesis.” Levy Economics Institute of Bard College Working Paper No. 74.

Minsky, H.P. 1970. "Financial Instability Revisited: The Economics of DisasterFundamental Reappraisal of the Discount Mechanism.” Board of Governors of the Federal Reserve System.

Modigliani, F., and M.H. Miller. 1958. "The Cost of Capital, Corporate Finance and the Theory of Investment.” American Economic Review 48: 261.

Morgan, D.P. 2002. "Rating Banks: Risk and Uncertainty in an Opaque Industry.” American Economic Review 92: 874-88.

Muellbauer, J. 2012. “When is a Housing Market Overheated Enough to Threaten Stability?” University of Oxford Department of Economics Discussion Paper, September.

Myers, S. 1977. “The Determinants of Corporate Borrowing.” Journal of Financial Economics 5: 147-75.

Myers, S.C., and R.G. Rajan. 1998. “The Paradox of Liquidity.” Quarterly Journal of Economics 113: 733-71.

Norton, J.O. 2013. “A More Prominent Role For The Leverage Ratio In The Capital Framework.” Remarks to the Florida Bankers Association, Orlando, February 6. Available at: <http://www.fdic.gov/news/news/speeches/spfeb0613.html>.

Occhino, F., and A. Pescatori. 2010. “Debt Overhang in a Business Cycle Model.” Federal Reserve Bank of Cleveland Working Paper 10-3R, December. Available at: http://www.clevelandfed.org/research/workpaper/2010/wp1003.pdf

Office of the Superintendent of Financial Institutions Canada, Guideline A: Capital Adequacy Requirements (Nov. 2007).

Rochet, J.-C. 1992. "Capital requirements and the behavior of commercial banks.” European Economic Review 36: 1137.

Saunders, A., E. Strock, N. Travlos. 1990. “Ownership structure, deregulation, and bank risk taking.” Journal of Finance 45: 643.

Schembri, L. 2014. "Housing Finance in Canada: Looking Back to Move Forward.” National Institute Economic Review, November.

Schoenmaker, D. 2014. “Regulatory Capital: Why Is It Different?” Mimeo. Duisenberg School of Finance, November. 
SEC (2015). Proposed Rule, “Listing Standards for Recovery of Erroneously Awarded Compensation.”

Sharpe, W.F. 1978. "Bank Capital Adequacy, Deposit Insurance and Security Values.” Journal of Financial and Quantitative Analysis 13: 701-18.

Shin, H.S., and T. Adrian. 2008. "Liquidity and Leverage.” Paper presented at the "Financial Cycles, Liquidity, and Securitization” conference hosted by the International Monetary Fund, Washington, DC, April 18. Available at: http://www.imf.org/external/np/seminars/eng/2008/fincycl/pdf/adsh.pdf

Shleifer, A., and R.W. Vishny. 2011. "Fire Sales in Finance and Macroeconomics.” Journal of Economic Perspective 25: 29.

Shleifer, A., and R.W. Vishny. 1992. "Liquidation Values and Debt Capacity: A Market Equilibrium Approach.” Journal of Finance 47: 134-66.

Simkovic, M. 2009. “Secret Liens and the Financial Crisis of 2008.” American Bankruptcy Law Journal 83: 253.

Smith, C.W., and R.M. Stulz. 1985. "The Determinants of Firms’ Hedging Policies.” Journal of Financial and Quantitative Analysis 20: 391-405.

Stein, J.C. 2011. “Monetary Policy as Financial-Stability Regulation.” NBER Working Paper No. 16883.

Stein, J.C. 2010. “Securitization, shadow banking and financial fragility.” Daedalus 139: 41.

Stone, R.B. 1967. "Debt-Equity Distinctions in the Tax Treatment of the Corporation and its Shareholders.” Tulane Law Review 42: 251.

Swiss National Bank, Financial Stability Report 5 (2013), available at http://www.snb.ch/en/mmr/reference/stabrep_2013/source/stabrep_2013.en.pdf.

Tett, G. 2009. Fool's Gold: How Unrestrained Greed Corrupted a Dream, Shattered Global Markets and Unleashed a Catastrophe. Boston: Little, Brown.

Thurner, S., J.D. Farmer, and J. Geanakoplos. 2010. "Leverage causes fat tails and clustered volatility.” Cowles Foundation Discussion Paper No. 1745, January.

Turner, A. 2010. "Something old and something new: Novel and familiar drivers of the latest crisis.” Speech, European Association of Banking and Financial History, May 21.

US Bankruptcy Court of the District of New York. 2010. "Final Report of Anton R. Valukas, Bankruptcy Court Examiner, in re: Lehman Brothers Holdings Inc. et al, Chapter 11 Case No. 08-13555 (JMP).” March 11. 
Vickers, J. 2011. “The Independent Commission on Banking: Final Recommendations.” Available at:

http://webarchive.nationalarchives.gov.uk/+/bankingcommission.independent.gov.uk.

Vinals, J. 2012. "Monetary Policy and Financial Stability: Challenges in the Wake of the Crisis.” International Journal of Central Banking January: 297-300.

Wachter, S. 2015. “The Housing and Credit Bubbles in the US and Europe: A Comparison.” Journal of Money, Credit and Banking 47(S1): 37-42. 